University of Wollongong

Research Online

Faculty of Engineering and Information

Faculty of Engineering and Information

Sciences - Papers: Part B

Sciences

2017

Behavior of self-compacting concrete columns reinforced longitudinally with steel tubes

Muhammad N. S Hadi

University of Wollongong, mhadi@uow.edu.au

Faez Alhussainy

University of Wollongong, fama867@uowmail.edu.au

M Neaz Sheikh

University of Wollongong, msheikh@uow.edu.au

Follow this and additional works at: https://ro.uow.edu.au/eispapers1

Part of the Engineering Commons, and the Science and Technology Studies Commons

Research Online is the open access institutional repository for the University of Wollongong. For further information contact the UOW Library: research-pubs@uow.edu.au 


\title{
Behavior of self-compacting concrete columns reinforced longitudinally with steel tubes
}

\begin{abstract}
This study investigates the behavior of self-compacting concrete (SCC) specimens reinforced with smalldiameter steel tubes in lieu of reinforcing bars. Twenty specimens were cast and tested. Four specimens were reinforced with normal steel bars (reference specimens) and the remaining 16 with steel tubes. All specimens contained steel helices with a pitch of either $50 \mathrm{~mm}$ or $75 \mathrm{~mm}$. Deformed steel bars of 16-mm diameter were used in the four reference specimens as longitudinal reinforcement. Steel tubes of 33.7-mm outside diameter with 2-mm wall thickness (ST33.7) and steel tubes of 26.9-mm outside diameter with 2.6-mm wall thickness (ST26.9) were used as longitudinal reinforcement in the remaining 16 specimens. The specimens were divided into five groups with four specimens in each group. From each group, one specimen was tested under concentric load, one under 25-mm eccentric load, one under 50-mm eccentric load, and one under flexural load. Although the nominal yield tensile strength of the steel bars was 150 and $250 \mathrm{MPa}$ greater than the nominal yield tensile strength of steel tubes ST33.7 and ST26.9, respectively, the results revealed that steel tube reinforced self-compacting concrete (STR SCC) specimens have ultimate load similar to reference specimens. Ductility of concentrically loaded STR SCC specimens was higher than that of the reference specimens. This study also reveals the challenges associated with using steel tubes as longitudinal reinforcement in STR SCC column specimens due to slip of steel tubes in concrete and explores remedial measures for the slip of steel tubes.
\end{abstract}

\section{Keywords}

columns, reinforced, longitudinally, behavior, steel, self-compacting, tubes, concrete

\author{
Disciplines \\ Engineering | Science and Technology Studies
}

\section{Publication Details}

Hadi, M. N. S., Alhussainy, F. \& Sheikh, M. Neaz. (2017). Behavior of self-compacting concrete columns reinforced longitudinally with steel tubes. Journal of Structural Engineering, 143 (6),

04017024-1-04017024-14. 


\section{Behavior of Self-Compacting Concrete Columns Reinforced Longitudinally \\ with Steel Tubes}

${ }^{1}$ Associate Professor, School of CME Engineering, University of Wollongong, Australia. Email: $\underline{\text { mhadi@uow.edu.au }}$, *Corresponding author Faez Alhussainy $^{2}$

${ }^{2}$ Ph.D. Candidate, School of CME Engineering, University of Wollongong, Australia. Email: fama867@uowmail.edu.au

M. Neaz Sheikh ${ }^{3}$

${ }^{3}$ Senior Lecturer, School of CME Engineering, University of Wollongong, Australia. Email: $\underline{\text { msheikh@uowmail.edu.au }}$

\section{Abstract}

This study investigates the behavior of Self-Compacting Concrete (SCC) specimens reinforced with small diameter steel tubes in lieu of reinforcing bars. Twenty specimens were cast and tested. Four specimens were reinforced with normal steel bars (reference specimens) and the remaining 16 with steel tubes. All specimens contained steel helices with a pitch of either $50 \mathrm{~mm}$ or $75 \mathrm{~mm}$. Deformed steel bars of $16 \mathrm{~mm}$ diameter were used in the four reference specimens as longitudinal reinforcement. Whilst steel tubes of $33.7 \mathrm{~mm}$ outside diameter with $2 \mathrm{~mm}$ wall thickness (ST33.7) and steel tubes of $26.9 \mathrm{~mm}$ outside diameter with $2.6 \mathrm{~mm}$ wall thickness (ST26.9) were used as longitudinal reinforcement in the remaining 16 specimens. The specimens were divided into five groups with four specimens in each group. From each group, one specimen was tested under concentric load, one under 25 $\mathrm{mm}$ eccentric load, one under $50 \mathrm{~mm}$ eccentric load and one under flexural load. Although 
the nominal yield tensile strength of steel bar was 150 and $250 \mathrm{MPa}$ greater than the nominal

27 yield tensile strength of steel tubes ST33.7 and ST26.9, respectively, the results revealed that Steel Tubes Reinforced Self-Compacting Concrete (STR SCC) specimens have ultimate load similar to reference specimens. Ductility of concentrically loaded STR SCC specimens was higher than reference specimen. This study also reveals the challenges associated with using steel tubes as longitudinal reinforcement in STR SCC column specimens due to slip of steel tubes in concrete and explores remedial measures for the slip of steel tubes.

Keywords: Composite columns; self-compacting concrete; steel bars; steel tubes; stressstrain behavior; debonding.

\section{Introduction}

Performance of concrete column has been widely improved by using composite material systems such as encased sections and concrete-filled tubes (Shanmugam and Lakshmi 2001). Different combinations of encased section and steel section were widely studied. The characteristics of the composite columns are governed by the geometric configuration and strength of materials. Steel sections and concrete have been used to construct composite columns with different cross-sections. The synergies between steel and concrete in composite columns provide better performance in terms of high strength, stiffness, ductility as well as fire and seismic resistance (Sakino et al. 2004; Giakoumelis and Lam 2004 and Choi and Xiao 2010). Concrete-filled steel tube (CFT) columns consist of a steel tube and concrete infill. In some cases internal steel reinforcement is used to provide proper connections between the concrete members (Moon and Lehman 2013). Another advantage of using internal steel reinforcement is to enhance the strength of the concrete columns, because the concrete core of these columns is confined by both steel tube and internal confinement 
reinforcement (Xiamuxi and Hasegawa 2012). Steel tube confines the concrete in a triaxial state. Therefore, a few stirrups can be used in the reinforced concrete column confined with thin-walled steel tube (Wang et al. 2015).

Composite columns offer considerable improvements over conventional columns reinforced with steel bars and are used in many structural applications. In traditional reinforced concrete columns, solid steel bars are used as longitudinal reinforcement. In this study, small diameter steel tubes were used as longitudinal reinforcement for concrete columns. Steel tubes that have the same cross sectional area as solid bars have higher second moment of area and radius of gyration than solid bars. Filling these steel tubes with concrete can further increase the yield and ultimate strength as well as the ductility of the concrete columns under axial compression load. This is because the concrete infill will contribute in delaying the local buckling and converts the failure mode of steel tube wall from inward to outward ANSI/AISC 360-10 (AISC 2010). For eccentric and flexural loading, using concrete filled steel tubes in lieu of solid bars may increase the stiffness of the cracked concrete section of the specimens, as the second moment of area of the cracked cross section for the steel tubes reinforced specimen is slightly higher than that of steel bars reinforced specimen. This is mostly due to the presence of the confined concrete inside the steel tubes. In addition, a circular tube section provides better confinement of concrete than other tube sections because the tube wall resists the concrete pressure by membrane-type hoop stresses instead of the plate bending (Sehneider 1998). Since, the diameter of these steel tubes is quite small to be filled with the normal concrete, high flowability concrete is needed to completely fill the tube without segregation. The Self-Compacting Concrete (SCC) is considered a suitable option. 
The SCC is an innovative material that can be used in complex forms and members that contain congestion of reinforcement, without needing vibration as it is able to compact under its own weight (Goodier 2003; De Schutter 2005 and EFNARC 2005). Han and Yao (2004) showed that the SCC is very suitable for CFT columns due to rheological properties of the SCC. Roeder et al. (2010) indicated that the empty tube could be filled with concrete rapidly by using SCC, without requiring any vibration. Muciaccia et al. (2011) explained that the use of SCC in-filled steel tube columns provides ease to construct difficult shapes and it reduces the cost as no vibration is required. It was also found that the use of SCC in lieu of normal concrete did not affect the design requirements of the CFT columns. Use of SCC can help in investigating new types of composite concrete columns in order to gain better stiffness, ductility and strength of concrete columns.

The above review of literature shows that no study has yet been conducted on the behavior of concrete columns reinforced with longitudinal small diameter steel tubes. It is expected that use steel tubes filled with SCC as reinforcement will decrease the overall buckling of longitudinal reinforcement and consequently increase the ductility of the column. Also, steel tubes will effectively confine the infill concrete resulting in an increase of the axial compressive strength. Hence, significant research investigations are needed to explore the behavior of columns reinforced with small diameter steel tubes filled with SCC (STR SCC column). This study provides a basis for using steel tubes instead of the conventional steel reinforcing bars as a new method for reinforcing concrete columns. It also reveals the problems associated with the use of plain steel tubes as longitudinal reinforcement in STR SCC column specimens due to the slip of steel tubes in concrete. Remedial measures for the problem associated with the slip of steel tubes have also been investigated. 


\section{Experimental Program}

101

102

103

A total of 20 circular SCC specimens reinforced longitudinally with steel bars and tubes were cast and tested at the High Bay Laboratory of the University of Wollongong, Australia. All specimens have the same dimensions: $240 \mathrm{~mm}$ in diameter, $800 \mathrm{~mm}$ in height and a height to diameter ratio of 3.3. The dimensions of the tested specimens were chosen to be suitable to the condition and capacity of the available testing facilities in the laboratory. It is noted that vertical support member with height-to-diameter (L/D) ratio greater than or equal to 2.5 is considered as a column in Canadian Standards CAN/CSA S6-06 (CSA 2006). Moreover, ACI 318-11 (ACI 2011) defined column as a member mainly used to support the axial compressive load with height-to-least lateral dimension ratio more than 3.

The SCC mix with a nominal compressive strength of $50 \mathrm{MPa}$ was used in casting the specimens. The maximum aggregate size used in the SCC mix was $10 \mathrm{~mm}$. The mix proportion of the SCC used in this study is shown in Table 1. All longitudinal steel tubes (33.7 $\mathrm{mm}$ and $26.9 \mathrm{~mm}$ outside diameters) were also filled with the SCC during the casting of the specimens. The specimens were divided into five groups with four specimens in each group. From each group, one specimen was tested under concentric load, two specimens were tested under 25 and $50 \mathrm{~mm}$ eccentric loads, and the last specimen was tested as a beam under flexural load (four-point load bending). The first group contained specimens reinforced with steel bars and considered as reference specimens and the remaining specimens were reinforced with steel tubes. All specimens were reinforced transversally with plain R10 (10 mm diameter plain steel bars) steel helices with a nominal tensile strength of $250 \mathrm{MPa}$. The specimens in the first group were reinforced longitudinally with six deformed steel bars of 16 $\mathrm{mm}$ diameter and nominal tensile strength of $500 \mathrm{MPa}$. The specimens in the second and third groups were reinforced longitudinally with six steel tubes of $33.7 \mathrm{~mm}$ outside diameter, 

specimens in the fourth and fifth groups were reinforced longitudinally with six steel tubes of $26.9 \mathrm{~mm}$ outside diameter, $2.6 \mathrm{~mm}$ in thickness and nominal tensile strength of $250 \mathrm{MPa}$ (ST26.9). Steel helices with $50 \mathrm{~mm}$ pitch were used in reinforcing the specimens transversally in the first, second and the fourth groups. The pitch of the steel helix satisfies ACI 318-14 (ACI 2014) requirements. The specimens in the third and fifth groups were reinforced transversally with $75 \mathrm{~mm}$ pitch steel helices. The specifications and reinforcement details of tested specimens are shown in Table 2 and Figure 1.

Table 2 shows the group names and specimen labels. The groups are labelled in two parts and the specimens are labelled in three parts. In the first part of the group names and specimen labels, the letters ( $\mathrm{N}$ and ST) refer to the type of the longitudinal reinforcement in the specimen. The letter $\mathrm{N}$ refers to deformed steel bars and the letters ST refer to the steel tubes. The number 16 refers to deformed steel bars of $16 \mathrm{~mm}$ diameter with a nominal tensile strength of $500 \mathrm{MPa}$. The number 33.7 refers to the steel tubes with $33.7 \mathrm{~mm}$ outside diameter and $2 \mathrm{~mm}$ wall thickness and with a nominal tensile strength of $350 \mathrm{MPa}$. The number 26.9 refers to the steel tubes with $26.9 \mathrm{~mm}$ outside diameter and $2.6 \mathrm{~mm}$ wall thickness and with a nominal tensile strength of $250 \mathrm{MPa}$. In the second part of the group names and specimen labels, the set of a letter and numbers refer to the helix pitch. H50 represents a $50 \mathrm{~mm}$ pitch and $\mathrm{H} 75$ represents a $75 \mathrm{~mm}$ pitch of the transverse reinforcement. In the third part of the specimen label refers to the type of the loading condition. The $\mathrm{C}$ refers to the concentric loading, E25 refers to the $25 \mathrm{~mm}$ eccentric loading, E50 refers to the $50 \mathrm{~mm}$ eccentric loading and $\mathrm{F}$ refers to the flexural loading (four-point load bending). For example, ST33.7-H50-E50 refers to the specimen that reinforced longitudinally with six ST33.7 steel tubes and transversally with a pitch of $50 \mathrm{~mm}$ helix and tested under 50-mm eccentric load. 
Self-compacting concrete was prepared according to EFNARC (2002) method. A number of concrete mixes were investigated to achieve self-compacting concrete. The properties of fresh concrete were tested according to ASTM C1610-14 (ASTM 2014b); ASTM C1611-14 (ASTM 2014c) and ASTM C1621-14 (ASTM 2014d). For the water/powder ratio of 0.4, column segregation test according to ASTM C1610-14 (ASTM 2014b), slump flow test according to ASTM C1611-14 (ASTM 2014c) and J-ring test according to ASTM C1621-14 (ASTM 2014d) were carried out. The test results were found to be satisfactory. All the specimens were cast using ready-mixed self-compacting concrete supplied by a local company. The average compressive strength of the SCC was $57 \mathrm{MPa}$ at 28 days. Two different steel bars were used in this study, deformed steel N16 bars (16-mm diameter deformed bars with $500 \mathrm{MPa}$ nominal tensile strength) for longitudinal reinforcement in the first group (reference specimens) and plain mild steel R10 bars (10-mm diameter plain bars with $250 \mathrm{MPa}$ nominal tensile strength) for transverse reinforcement in all specimens. Three samples of N16 deformed bars and R10 plain bars were tested in accordance with Australian Standard AS 1391-2007 (AS 2007). Results of testing revealed that the N16 steel bar experienced strain hardening behavior with an obvious yield stress. However, the yield stress of the R10 plain bar was not easily identified and was determined using the $0.2 \%$ proof stress. $195 \mathrm{GPa}$, respectively.

Two different steel tubes were used to reinforce remaining specimens in the longitudinal direction: steel tubes ST33.7 and ST26.9. Three samples of each ST33.7 and ST26.9 tubes were tested in accordance with ASTM A370-14 (ASTM 2014a). Steel plugs were designed 
based on the inner diameters of the steel tubes to suit the 29.7 and $21.7 \mathrm{~mm}$ steel tubes in tensile testing. Yield stresses of both steel tubes were not easily identified with a strain plateau and were instead determined using the $0.2 \%$ proof stress. The average tensile strength and elastic modulus of ST33.7 were $450 \mathrm{MPa}$ and $196 \mathrm{GPa}$, respectively. The average tensile strength and elastic modulus of ST26.9 were $355 \mathrm{MPa}$ and $192 \mathrm{GPa}$, respectively.

The bond stress between different longitudinal reinforcement and SCC was determined using pull-out tests according to RILEM (1983). For each reinforcing type, three specimens were tested on the $28^{\text {th }}$ day. The average bond stress of N16 steel bars was $19 \mathrm{MPa}$ at failure. The specimens with N16 steel bar failed due to pull-out. The average bond stress of ST33.7 and ST26.9 steel tubes filled with the SCC was 1.5 and $0.75 \mathrm{MPa}$, respectively at failure. The specimens with SCC filled ST33.7 and ST26.9 failed due to slip.

\section{Specimen Preparation and Testing}

\section{Formwork}

PVC pipes with a $240 \mathrm{~mm}$ inner diameter were used as formwork molds for the concrete column specimens. The PVC pipe was cut for a length of $800 \mathrm{~mm}$. Twenty pieces of PVC pipe molds were prepared. These pipe molds were then fixed to a non-absorbing plywood base plate. The formwork was constructed to keep both the top and bottom of the molds in a fixed plumb position. The formwork was secured to a rigid pallet onto which the base plate was mounted as shown in Figure 2.

\section{Longitudinal and Transverse Reinforcement}

The internal longitudinal reinforcement bars and steel tubes were prepared and cut at $760 \mathrm{~mm}$ in order to provide $20 \mathrm{~mm}$ clear cover at the top and bottom of the reinforcement cage. In 
addition, the transverse steel helices were prepared by forming helices with a $200 \mathrm{~mm}$ outer diameter and pitches of 50 and $75 \mathrm{~mm}$. In constructing the reinforcing cages, the longitudinal reinforcement was tied with equal spacing to the inside of the helices following the test matrix in Table 2 and Figure 1.

To construct the reinforcement cages, two $12 \mathrm{~mm}$ thick circular plastic templates were made.

The diameters of the holes in the templates were designed to suit various tube and bar sizes as designed to hold both ST26.9 and ST33.7 steel tubes, whilst circular template 2 was designed to hold the N16 bars. Figure 3 shows the schematics of circular templates. Each circular template contained six half circles holes at the circumference to hold the longitudinal reinforcement. These holes were created at equal distances on the circumference of the circular template. The two identical circular templates were setup parallel to each other at the top and bottom by using a threaded steel rod. Hex steel nuts, washers and lock washers were used to fix these two circular templates at required distance to the threaded steel rod. Figure 4(a \& b) shows the setup of circular templates for different longitudinal reinforcement. In addition, two aluminum forms were designed as a spacer for holding the helices at the desired pitch, as shown in Figure 4(c). The aluminum forms have grooves to adjust the spacing of helices at 50 and $75 \mathrm{~mm}$. All longitudinal steel bars or steel tubes were tied together with the helix by using tie wire. Figure 5 shows 20 fabricated reinforcing cages.

Testing of the Specimens

222 The Denison 5,000 kN compression testing machine was used for testing all the specimens. Of the 20 specimens, 15 were tested as columns in compression tests. The top and bottom of the column specimens were wrapped by two layers of CFRP sheets with $100 \mathrm{~mm}$ overlap to 
avoid premature failure of the concrete during axial compression tests. Also, the top and bottom end surfaces of the columns were capped with high strength plaster to ensure a uniform distribution of the applied loads. The plaster was poured into the loading head molds at the bottom end first and left to cure for 30 minutes before the column specimen was turned over and similarly the plaster was poured into the top loading head mold in order to cap the top end.

For applying the eccentric loading on the column, steel loading heads manufactured at the University of Wollongong were used. The loading heads were used to transfer the load generated by the machine into the column specimen causing lateral deflection $(\delta)$. Steel loading heads consisted of two parts: a circular steel plate adapter and steel plate with ball joint, as shown in Figure 6(a). A steel ball joint was installed on a steel plate to induce eccentricities (e) of $25 \mathrm{~mm}$ and $50 \mathrm{~mm}$ to the top and bottom loading heads. Concentric loading however was applied directly through the circular steel plates attached at both ends of the column specimen without any steel ball joints. To measure the axial deformation of the column specimens, two linear variable differential transformers (LVDT) were used. The LVDTs were connected directly to the machine loading heads at opposite corners. A laser optical displacement sensor (LODS) was attached at the mid-height of the test specimen to measure lateral displacement under eccentric loading. In addition, before casting, strain gauges were attached on the two opposite longitudinal reinforcements (bars and tubes) to measure axial strain. The LVDTs, LODS and strain gauges were connected to the data logger which recorded measurements and saved on the control computer. Figure 6(b) shows the typical test setup of column specimens. 
249 Five specimens were tested as beams under flexural load (four-point load bending). Flexural loading system consisted of two circular steel loading rigs at the top and bottom of the beam specimens. These rigs were manufactured at the University of Wollongong to suit the Dension testing machine and $240 \mathrm{~mm}$ round specimens. The specimens were tested by using a four-point load bending arrangement with the loads applied at L/3 distance from the supports, where $\mathrm{L}$ is the span length. To measure the mid span deflection $(\delta)$ of the beam specimen the same LODS was placed centrally underneath the rig. A slot at the bottom support of the rig allowed the LODS to optically measure the deflection. The LODS was connected to the data logger which recorded the results. Figure 7 shows the schematic details of the four-point load bending test arrangements. All tests were carried out at the displacement controlled loading rate of $0.3 \mathrm{~mm} / \mathrm{min}$ and the data was recorded at every 2 seconds.

\section{Experimental Results and Analysis}

\section{Column Specimens under Concentric Load}

264 Five specimens were tested under concentric axial compression until failure. Table 3 reports the test results. Figure 8 shows the axial load-axial deformation diagrams of the five concentrically tested specimens. For all specimens, initial failure of the concrete cover started with cracks after the maximum load was reached. As the loading continued to increase the buckling of longitudinal reinforcement occurred at the mid-height of the column specimens. Finally, the specimens failed by fracture of the steel helices at the mid-height. The failure modes of the specimens are shown in Figure 9. The average strains in the longitudinal steel bars and steel tubes indicated that steel bars and tubes yielded at the maximum axial load.

272 The axial deformation corresponding to the first helix fracture in Specimen N16H50C was 20 mm, while in Specimen ST33.7H50C and Specimen ST26.9H50C were 33.5 and $36 \mathrm{~mm}$, 
respectively. Specimen N16H50C had a lower axial deformation at the first fracture because the N16 steel deformed bar buckled earlier than the steel tubes. Consequently more pressure was applied on the steel helix and caused the yielding and fracture of steel helices. Due to the tensile strengths being different, the force contribution of steel tubes ST33.7 and ST26.9 in Specimen ST33.7H50C and Specimen ST26.9H50C were less than N16 steel bars in the reference Specimen N16H50C by $19.9 \%$ and 37\%, respectively. Nevertheless, Specimen ST33.7H50C had similar yield and maximum load as the reference Specimen N16H50C. Specimen ST26.9H50C had only 5\% less maximum load than the reference specimen. Circular steel tubes provided confinement to the concrete and increased the compressive strength of concrete which resulted in enhancing the capacity of the columns. Besides, the ultimate axial deformation at failure for Specimen ST33.7H50C and Specimen ST26.9H50C were higher than the reference Specimen N16H50C (Table 3).

For the increase of the pitch of helices from 50 to $75 \mathrm{~mm}$ in the specimens reinforced with steel tubes ST26.9, the maximum axial load reduced by $6 \%$. Whereas, increasing the pitch of helices from 50 to $75 \mathrm{~mm}$ in the specimens reinforced with steel tubes ST33.7, the maximum axial load reduced by only $3.5 \%$. The reason for the differences in the reduction of maximum axial load is associated with the slenderness (L/D) ratio for steel tubes. The slenderness of steel tube ST26.9 is higher than the slenderness of steel tube ST33.7. From the test results, it was observed that specimens reinforced with ST33.7 steel tubes had the yield and maximum load capacity greater than specimens reinforced with ST26.9 steel tubes. This is because the ST33.7 has higher nominal tensile strength than ST26.9. Besides, the larger internal diameter of the ST33.7 tubes allowed for a large concrete to be filled inside the tube which contributed in increasing the capacity of the specimens as the confined concrete inside the tube positively contributed to the compressive strength of the specimen. 
299 To study the behavior of circular column specimens reinforced longitudinally with steel 300 tubes, it is important to investigate the ductility of the specimens, which provides an 301 indication of the post peak axial load-axial deformation behavior. In this paper, the ductility was calculated as the ratio of the area under the curve up to the ultimate deformation to the area under the curve up to the yield deformation (Hadi 2009). In order to specify yield deformation, the secant line was drawn from the origin to the point of 0.75 times of the first peak load. Then, the yield deformation was specified on the ascending load-deformation curve as corresponding to the intersection point of the extension secant line and a horizontal line from the first peak load (Foster and Attard 1997).

For concentric load, the ductility of the column specimens reinforced with steel tubes were higher than the column specimens reinforced with steel bars for the same pitch of helix. The ductility of Specimen ST33.7H50C and Specimen ST26.9H50C were 30\% higher than the reference specimen (Table 3). In spite of increasing the pitch of helix from 50 to $75 \mathrm{~mm}$ in the Specimen ST26.9H75C, the ductility of Specimen ST26.9H75C was $11 \%$ higher than the reference specimen. However, the Specimen ST33.7H75C has ductility lower than the reference Specimen by $18 \%$. This is mainly because Specimen ST33.7H75C has higher yield deformation than the reference specimen by about $13 \%$ (Table 3 ).

\section{Column Specimens under Eccentric Load}

Ten specimens were tested under eccentric loading, five of which under $25 \mathrm{~mm}$ eccentric load and five under $50 \mathrm{~mm}$ eccentric load. Test results of specimens under $25 \mathrm{~mm}$ eccentric loading are given in Table 4. Figure 10 shows the axial load-axial deformation and axial loadlateral deformation diagrams of the specimens under $25 \mathrm{~mm}$ eccentric loading. For all specimens tested, the initial failure occurred as a result of cracks in the concrete cover once 
the specimens reached their maximum load. This was followed by a small drop in the maximum load due to spalling of concrete cover. After that, reference Specimen N16H50E25 showed an increasing load. The load increased to a value less than the first maximum load. On the other hand, specimens reinforced with steel tubes showed a steady reduction in the load-deformation curve after spalling of concrete cover. This is because the debonding between steel tubes and concrete took place during the testing. For specimens reinforced with steel tubes, the failure occurred as results of a buckling of the longitudinal steel tubes in the compression region. While the failure of the reference column specimen occurred due to the fracture in one of the longitudinal bars in the tension region combined with buckling in the longitudinal bars in the compression region, as shown in the Figure 11. After the completion of the testing, by drilling holes in the specimens, the slip in both steel bars and steel tubes was measured using a measurement tape. It was found that the slip in steel tube was $20 \mathrm{~mm}$ while no slip was observed in N16 steel bars.

To overcome the slip of steel tubes for column specimens reinforced with steel tubes under eccentric loading, $4 \mathrm{~mm}$ thick washers with two different inner diameters 34 and $27 \mathrm{~mm}$ were welded to both ends of ST33.7 and ST26.9 steel tubes, respectively. The washers were cut to three quarters of the shape. An initial attempt to prevent debonding was done on Specimen ST33.7H75E50 and Specimen ST26.9H75E50. At first, the locations of steel tubes were identified by mildly drilling the concrete cover. Secondly a ring of the concrete cover was removed carefully by using a chisel and a hummer in order to reveal the ends of the steel tubes. Thirdly, the washers were fitted and properly welded around the ends of the tubes. Finally, high strength plaster (compressive strength of $70 \mathrm{MPa}$ ) was used to fill the concrete cover. Figure 12 shows details of the remedial measure for the slip of steel tubes. 

still occurred even after the repair. This is because the concentrated stresses on the washers led to bending of washers and tearing the tubes near the welding area at both ends of the tube in the tension region. To solve this, for the remaining Specimen ST33.7H50E50 and Specimen ST26.9H50E50, two washers were welded at both ends of the longitudinal steel tubes in the tension region of each specimen (Figure 13). This was done in an attempt to distribute the tensile strain over four anchor points and prevent the first washer from bending by supporting it by the second washer. This attempt was also used to increase the resistant capacity of steel tube wall before tearing at the ends and overall slip.

Test results of specimens under $50 \mathrm{~mm}$ eccentric loading are reported in Table 5. Figure 14 shows the axial load-axial deformation and axial load-lateral deformation diagrams of the specimens tested under $50 \mathrm{~mm}$ eccentric loading. For all specimens tested, the initial failure occurred as a result of cracks within the concrete cover once the specimens reached their maximum load. This was followed by a small drop in the maximum load due to spalling of concrete cover. After that, reference Specimen N16H50E50 showed an increasing load. The load increased to a value less than the first maximum load. Axial load then steadily decreased until the failure occurred due to yielding of the longitudinal bars in the tension region combined with buckling of the longitudinal bars in the compression region. Also, Specimen ST33.7H50E50 experienced a similar yield point to the reference specimen after initial spalling of concrete cover but the tube tearing and failure did not occur at the center. Similarly for Specimen ST26.9H50E50, two washers were welded at both ends of the longitudinal tubes which were supposed to be in the tension region during testing. However, during testing the tubes with washer were placed inadvertently in the compression region rather than in the tension region resulting in a steady reduction in the load-deformation curve 
after spalling of concrete cover. As in Specimens ST26.9H75E50 and ST33.7H75E50, the tubes tore around the single washers after reaching the maximum load causing a slip with no signs of ductile behavior. However, placing the tubes with double washers in the compression region resulted in a higher load carrying capacity compared to the Specimen ST33.7H50E50. This indicated that the slip may also occur in tubes in compression loads as well as in tension under $50 \mathrm{~mm}$ eccentric loads. After spalling of concrete cover, the tube was compressed and slip in the compression region, as a result, the double washers prevented the slip in this case.

For $25 \mathrm{~mm}$ eccentric load, the ductility of the column specimens reinforced with steel tubes were lower than the column specimens reinforced with steel bars due to slip of steel tubes. For $50 \mathrm{~mm}$ eccentric load, the ductility of the column specimens reinforced with steel tubes were improved due to the use of washers, but still lower than the column specimens reinforced with steel bars.

\section{Flexural Specimens}

The remaining five specimens were tested under four-point load bending as beams. Test results of specimens under flexural loading are reported in Table 6. Figure 15 shows the loadmidspan deflection diagrams of the specimens tested under flexural loading. It is noted that span to depth ratio of the test specimen is relatively short and hence the failure may not truly represent pure bending condition. However, for uniformity and consistency, specimen dimensions have been kept the same as other specimens tested under concentric and eccentric axial compression. It was expected that the steel tubes in the tension region for the specimens under flexural would be subjected to higher tensile stresses compared to the specimens under 25 and $50 \mathrm{~mm}$ eccentric loads, with high possibility that slip would occur. To prevent slip of steel tubes inside these specimens, single washer and double washers were also used in the 
compression and tension regions, respectively. Because of the relatively large cross-section area of the specimens, precautions were taken to avoid any bearing and shear failures. Bearing plate spacers, $50 \mathrm{~mm}$ width were used on the testing rigs. Also, CFRP sheets were used to wrap the specimen ends leaving only one third in the middle.

402

For all specimens, the failure mechanism was consistent. The initial failure occurred as a result of cracks within the concrete cover in the middle when maximum load was reached. This was followed by yielding and then fracture of the farthest bar or tube in the tension region. Afterword, the other bars or tubes in the tension region either fractured or kept yielding for a while and then fractured depending on the stresses distribution and corresponding generated cracks. The failure modes of specimens tested under flexural loading are shown in Figure 16. However, for specimens reinforced with steel tubes, the initial slope of load-midspan deflection diagrams in the specimens reinforced with tubes of a $350 \mathrm{MPa}$ nominal tensile strength (ST33.7) was steeper than other specimens reinforced with tubes of a $250 \mathrm{MPa}$ nominal tensile strength (ST26.9). It is clear that the large diameter ST33.7 tube have a higher second moment of area. This greater second moment of area provides a higher stiffness combined with the higher nominal tensile strength of steel in the ST33.7. Also, the effect of tensile strength on the maximum load was higher than the effect of the pitch. The lowest value of the maximum load was in Specimen ST26.9H75F and then Specimen ST26.9H50F.

For flexural load, the ductility of the specimens reinforced with steel tubes was lower than the specimens reinforced with steel bars. The ductility of Specimen ST33.7H50F and Specimen ST33.7H75F were less than the reference specimen by $29 \%$ and $33 \%$, respectively (Table 6).

422 The reason for this is that the tensile strength of steel tubes was lower than the tensile 
strength of the steel bars. In addition, the effect of tensile strength longitudinal reinforcing steel on the ductility of specimens was higher than the effect of the spacing of the pitch. The lowest value of the ductility was observed in Specimen ST26.9H75F and Specimen ST26.9H50F (Table 6).

\section{Interaction Diagrams}

The experimental axial load-bending moment (P-M) interaction diagrams of all specimen types are shown in Figure 17. Four points that are concentric, $25 \mathrm{~mm}$ eccentric, $50 \mathrm{~mm}$ eccentric and flexural loading were used to draw the P-M interaction diagrams. The first point consisted of maximum axial load for specimens tested under concentric load. The second and the third points consisted of the maximum axial load for specimens tested under 25 and $50 \mathrm{~mm}$ eccentric loads and the corresponding bending moments, respectively. The corresponding bending moments at the mid-height of the columns under 25 and $50 \mathrm{~mm}$ eccentric loads were calculated as in Equation 1.

$$
M=P_{M a x}(e+\delta)
$$

Where $M$ and $\delta$ represent moment and lateral deformation corresponding to the maximum axial load $\left(P_{\text {Max }}\right)$, respectively, and $e$ represents the loading eccentricity. The fourth point consisted of only pure bending moment for the specimen tested under four point bending.

The pure bending moments at mid span of the beams were calculated as in Equation 2.

$$
M_{p}=\left(P_{M a x} l\right) / 6
$$

443 Where $M_{p}$ represents pure bending moment corresponding to the maximum load $\left(P_{\text {Max }}\right)$ of 444 the tested beam specimen, and the $l$ represents span length, or the distance between the supports. 
447 Specimens of Group ST33.7H50 showed similar axial load-bending moment interaction

448 behavior to the reference specimens of Group N16H50. At the concentric load and $25 \mathrm{~mm}$ eccentric load, the axial load and bending moment capacities of specimens of Group ST33.7H50 were similar to the axial load and the bending moment capacities of the reference specimens of Group N16H50. At $50 \mathrm{~mm}$ eccentric load, the maximum axial load of Specimen ST33.7H50E50 was lower than the maximum axial load of reference specimen by $5 \%$. This is because the use of a single washer for the longitudinal steel tubes was insufficient to prevent the slip of tubes in the compression region of the specimen. For flexural load, the bending moment of Specimen ST33.7H50F was 3.4\% lower than the bending moment of N16H50F due to the lower tensile strength of longitudinal tube reinforcement compared to steel bars. Increasing the pitch of the helices in the specimen from $50 \mathrm{~mm}$ to $75 \mathrm{~mm}$ resulted in the reduction of the axial load carrying capacity and bending moments under concentric, eccentric and flexural loads of Group ST33.7H75.

460

At the concentric load and $25 \mathrm{~mm}$ eccentric load, specimens of Group ST26.9H50 showed lower axial load carrying capacity compared to the specimens of Group ST33.7H50 because the lower tensile strength and small outside diameter steel tubes. However, at $50 \mathrm{~mm}$ eccentric load, placing the steel tubes with double washers in the compression region of the Specimen ST26.9H50E50 resulted in a higher axial load carrying capacity and corresponding bending moment compared to the Specimen ST33.7H50E50. Under flexural loads, the bending moment of the Specimen ST26.9H50F was 23.7\% and 21\% lower than the bending moment of reference Specimen N16H50F and Specimen ST33.7H50F, respectively. Similar to the specimens of Group ST33.7H75, increasing the pitch of the helices in the specimen from $50 \mathrm{~mm}$ to $75 \mathrm{~mm}$ resulted in the reduction of the axial load carrying capacity and

471 bending moments under concentric, eccentric and flexural loads of Group ST26.9H75. This 
indicates that the use of steel tubes with similar tensile strength of the steel bars may show

473 higher axial load carrying capacity and corresponding bending moment in STR SCC specimens. However, the slip of steel tubes should be prevented. Adequate use of washers may be considered a viable solution.

477 Theoretical axial load-bending moment (P-M) interaction diagrams of all specimen types were determined by layer-by-layer integration method. The cross-section of concrete is assumed to consist of small parallel layers with a small thickness $(t)$ and a variable width $\left(b_{n}\right)$, as shown in Figure 18. The number of layers $(n)$ is calculated by dividing the diameter of the cross-section $(D)$ on the thickness of each layer. The cross-section was divided into 240 small layers by assuming the thickness of each layer equal to $1 \mathrm{~mm}$. Based on the assumptions that plane sections remain plane after bending, the strain $\left(\varepsilon_{c, n}\right)$ in the center of each layer can be calculated according to the linear distribution of strain, as a function of the depth of neutral axis $\left(d_{n}\right)$ (Figure 18). The $d_{n}$ is represented the distance from the extreme concrete compressive fiber to the neutral axis $(N . A)$. After calculating the strain in each concrete layer, the corresponding stress value $\left(f_{c, n}\right)$ on the center of each layer is calculated according to the stress-strain model for unconfined concrete in Aslani and Nejadi (2012). The tensile strength of concrete is ignored in the calculations. The unconfined concrete strength is taken as $83 \%$ of 28-day cylinder compressive strength according to AS 3600-2009 (AS 2009). The ultimate strain in extreme concrete compressive fiber has been considered as 0.003 according to AS 3600-2009 (AS 2009).

The force reaction in the center of each concrete layer $\left(P_{c, n}\right)$ is calculated by multiplying the stress in each layer by the corresponding area of concrete in each layer $\left(A_{c, n}\right)$. The moment for each layer is calculated by multiplying the force in each layer by the distance from center 
497 of each layer to the centerline of the cross-section. The total force of the concrete cross498 section is calculated as the summation of the forces acting on the strips. The tensile forces are

499

500

501

502

503

504

505

506

507

508

509

510

511

512

513

514

515

516

517

518

519

520

521

Figure 19 compares the theoretical and the experimental $\mathrm{P}-\mathrm{M}$ interactions for the specimens tested in this study. It was found that the theoretical results were in good agreement with the experimental results. The experimental bending moment of specimens reinforced with N16 steel bar, ST33.7 steel tube and ST26.9 steel tube tested under four-point load bending was relatively greater than the calculated bending moment. This might be because specimens tested as beam had shear span shorter than twice the effective depth of the concrete crosssection.

\section{Conclusions}

Use of small diameter circular steel tubes filled with Self-Compacting Concrete (SCC) in lieu of conventional steel bars were investigated in reinforcing the concrete column. Hence, a new reinforcing method of the concrete column specimens was proposed in this paper. Problems associated with the use of steel tubes as longitudinal reinforcement in columns due to slip of steel tubes have been highlighted. The following conclusions can be drawn.

1. As the tensile strength of steel bars and steel tubes are different, the force contribution of ST33.7 steel tubes in Specimen ST33.7H50 was found to be less than the force contribution of N16 steel bars in the reference Specimen N16H50 by $19.9 \%$. In spite of less force contribution of steel tubes, the column Specimen ST33.7H50 had similar yield and maximum load as the reference Specimen N16H50 under concentric and $25 \mathrm{~mm}$ 
eccentric axial compression. The yield loads of the Specimens N16H50 and ST33.7H50 were 2505 and $2500 \mathrm{kN}$, respectively. The maximum loads of the Specimens N16H50 and ST33.7H50 were $2734 \mathrm{kN}$ and $2729 \mathrm{kN}$, respectively. Hence, using steel tubes with similar tensile strength to the steel bars might result in a higher maximum load capacity.

2. For concentric load and $25 \mathrm{~mm}$ eccentric load, specimens reinforced with ST33.7 steel tubes had maximum load capacity greater than specimens reinforced with ST26.9 steel tubes. For $50 \mathrm{~mm}$ eccentric load, however, Specimen ST26.9H50E50 showed maximum load higher than Specimen ST33.7H50E50 due to the slip of ST33.7 steel tubes.

3. In spite of the cross sectional area of ST33.7 and ST26.9 steel tubes are the same, increasing the pitch of helices from 50 to $75 \mathrm{~mm}$ resulted in a higher reduction in the maximum axial load of specimens reinforced with ST26.9 tubes compared to specimens reinforced with the ST33.7 tubes.

4. Under flexural loading, the maximum loads of the Specimens ST33.7H50F and ST26.9H50F were $7 \%$ and $25 \%$, respectively, lower than the reference Specimen N16H50F. In addition, the initial slope of load-midspan deflection diagrams in the specimens reinforced with ST33.7 tubes (nominal tensile strength=350 MPa) was steeper than the specimens reinforced with ST26.9 tubes (nominal tensile strength=250 MPa).

5. The ductility of Steel Tubes Reinforced Self-Compacting Concrete (STR SCC) specimens was significantly influenced by the slip of steel tubes under eccentric loading. However, the STR SCC specimens showed a higher ductility than the reference Specimen N16H50C under concentric loading.

6. Welding a single washer at the ends of the steel tubes to prevent slip of steel tubes in concrete was insufficient and resulted in tearing of the tubes near the welding area at both ends of the tube in the tension and compression regions. In contrast, welding double washers at the ends of the tubes prevented the slip of longitudinal steel tubes in concrete. 
548 The authors thank the University of Wollongong and technical officers at the High Bay 549 laboratory, especially Mr. Ritchie McLean, for their help in the experimental work of this 550 study. The authors also thank the Orrcon steel company for supplying the steel tubes. Finally, 551 the second author would like to acknowledge the Iraqi Government for the support of his $552 \quad \mathrm{PhD}$ scholarship.

553

\section{References}

555 ACI (American Concrete Institute). (2011). "Building code requirements for structural concrete." ACI: 318M-11, Farmington Hills, MI.

ACI (American Concrete Institute). (2014). "Building code requirements for structural concrete " ACI: 318M-14, Farmington Hills, MI.

AISC (American Institute of Steel Construction). (2010). "Specification for structural steel buildings." ANSI/AISC 360-10, Chicago, USA.

AS (Australian Standard). (2007). "Metallic materials-Tensile testing at ambient temperature." AS 1391-2007, Sydney, NSW, Australia.

AS (Australian Standard). (2009). "Concrete structure." AS 3600-2009, Sydney, NSW, Australia.

Aslani, F., and Nejadi, S. (2012). "Mechanical properties of conventional and selfcompacting concrete: An analytical study." Construction and Building Materials, 36, 330-347.

ASTM (American Society for Testing and Materials). (2014a). "Standard test method and 569 definition for mechanical testing of steel products." ASTM A370-14, West Conshohocken, PA, USA. 
571 ASTM (American Society for Testing and Materials). (2014b). "Standard test method for

572

573

574

575

576

577

578

579

580

581

582

583

584

585

586

587

588

589

590

591

592

593

594 static segregation of self-consolidating concrete using column technique." ASTM C1610/C1610M-14, West Conshohocken, PA, USA.

ASTM (American Society for Testing and Materials). (2014c). "Standard test method for slump flow of self-consolidating concrete." ASTM C1611/C1611M-14, West Conshohocken, PA, USA.

ASTM (American Society for Testing and Materials). (2014d). "Standard test method for passing ability of self-consolidating concrete by J-ring." ASTM C 1621/C 1621M-14, West Conshohocken, PA, USA.

Choi, K. K., and Xiao, Y. (2010). "Analytical model of circular CFRP confined concretefilled steel tubular columns under axial compression." Journal of Composites for Construction ASCE, 14(1), 125-133.

CSA (Canadian Standards Association). (2006). "Canadian highway bridge design code." CAN/CSA S6-6, Rexdale, ON, Canada.

De Schutter, G. (2005). "Guidelines for testing fresh self-compacting concrete." European Research Project Published by: Systematic pan-European inter-laboratory, 1-23.

EFNARC (The European Federation of Specialist Construction Chemicals and Concrete Systems). (2002). "Specification and guidelines for self-compacting concrete." 1-32, $<$ www.efnarc.org $>$.

EFNARC (The European Federation of Specialist Construction Chemicals and Concrete Systems). (2005). "The European guidelines for self-compacting concrete specification, production and use." 1-63, <www.efnarc.org >.

Foster, S. J., and Attard, M. M. (1997). "Experimental tests on eccentrically loaded highstrength concrete columns." ACI Structural Journal, 94(3), 295-303. 
595

596

597

598

599

600

601

602

603

604

605

606

607

608

609

610

611

612

613

614

615

616

617

618

Giakoumelis, G., and Lam, D. (2004). "Axial capacity of circular concrete-filled tube columns." Journal of Constructional Steel Research, 60, 1049-1068.

Goodier, C. I. (2003). "Development of self-compacting concrete." Proceedings of the Institution of Civil Engineers-Structures and Buildings, 156(4), 405-414.

Hadi, M. N. S. (2009). "Behaviour of eccentric loading of FRP confined fibre steel reinforced concrete columns." Construction and Building Materials, 23(2), 1102-1108.

Han, L.-H., and Yao, G.-H. (2004). "Experimental behaviour of thin-walled hollow structural steel (HSS) columns filled with self-consolidating concrete (SCC)." Thin-Walled Structures, 42(9), 1357-1377.

Moon, J., Lehman, D., Roeder, C., and Lee, H. (2013). "Strength of circular concrete-filled tubes with and without internal reinforcement under combined loading." Journal of Structural Engineering ASCE, 139(12), 04013012.

Muciaccia, G., Giussani, F., Rosati, G., and Mola, F. (2011). "Response of self-compacting concrete filled tubes under eccentric compression." Journal of Constructional Steel Research, 67(5), 904-916.

RILEM. (1983). "Bond test for reinforcing steel: 2. Pullout test." Recommendation RC 6, E \& FN SPON, London, 218-220.

Roeder, C. W., Lehman, D. E., and Bishop, E. (2010). "Strength and stiffness of circular concrete-filled tubes." Journal of Structural Engineering, 136(12), 1545-1553.

Sakino, K., Nakahara, H., Morino, S., and Nishiyama, I. (2004). "Behavior of centrally loaded concrete-filled steel-tube short columns." Journal of Structural Engineering ASCE, 130(2), 180-188.

Schneider, S. (1998). "Axially loaded concrete-filled steel tubes." Journal of Structural Engineering ASCE, 124(10), 1125-1138. 
619 Shanmugam, N. E., and Lakshmi, B. (2001). "State of the art report on steel-concrete 620 composite columns." Journal of Constructional Steel Research, 57(10), 1041-1080.

621 Wang, X., Liu, J., and Zhang, S. (2015). "Behavior of short circular tubed-reinforced-

622

623

624

625

626

627

628

629

630

631

632

633

634

635

636

637

638

639

640

641

642

643

644 concrete columns subjected to eccentric compression." Engineering Structures, 105, $77-86$.

Xiamuxi, A., and Hasegawa, A. (2012). "A study on axial compressive behaviors of reinforced concrete filled tubular steel columns." Journal of Constructional Steel Research, 76, 144-154.

(1)

8

(1)


645 List of Tables

646 Table 1: Mix proportion of the SCC used in this study

647 Table 2: Details of tested specimens

648 Table 3: Results of specimens tested under concentric loading

649 Table 4: Results of specimens tested under $25 \mathrm{~mm}$ eccentric loading

650 Table 5: Results of specimens tested under $50 \mathrm{~mm}$ eccentric loading

651 Table 6: Results of specimens tested under flexural loading

652

653

654

655

656

657

658

659

660

661

662

663

664

665

666

667

668

669 
671 Figure 1: Reinforcement details of test specimens

672 Figure 2: Construction of formwork

673 Figure 3: Circular templates

674 Figure 4: Fabrication of reinforcement cages: (a) longitudinal steel bars; (b) longitudinal steel 675 tubes; and (c) transverse reinforcement

676 Figure 5: Fabricated reinforcing cages

677 Figure 6: Typical test setup of column specimens: (a) loading heads; and (b) setup details of 678 specimen

679 Figure 7: Four-point load bending test arrangements

680 Figure 8: Axial load-axial deformation diagrams of specimens tested under concentric 681 loading

682 Figure 9: Failure modes of column specimens tested under concentric compression

683 Figure 10: Axial load- axial deformation and axial load-lateral deformation diagrams of 684 specimens tested under $25 \mathrm{~mm}$ eccentric loading

685 Figure 11: Failure mode of reference Specimen N16H50E25

686 Figure 12: Remedial measure for the slip of steel tubes: (a) specimen before repairing; (b)

687 drilling of concrete cover; (c) Specimen after removing the concrete cover above tubes; (d)

688 washers fitted on the tubes; (e) welding of washers; and (f) plaster infill.

689 Figure 13: The configuration of two washers: (a) washers before welding; and (b) washers 690 after welding

691 Figure 14: Axial load-axial deformation and axial load-lateral deformation diagrams of 692 specimens tested under $50 \mathrm{~mm}$ eccentric loading

693 Figure 15: Load-midspan deflection of specimens tested under flexural Loading

694 Figure 16: Failure modes of specimens tested under flexural loading 
695 Figure 17: Experimental load-bending moment interactions for the tested specimens

696 Figure 18: layers-by- layer integration method

697 Figure 19: Comparison between the theoretical and the experimental P-M interactions for the 698 tested specimens

699

700

701

702

703

704

705

706

707

708

709

710

711

712

713

714

715

716

717

718

719

720

721 
Table 1: Mix proportion of the SCC used in this study

\begin{tabular}{ll}
\hline Material & Quantity \\
\hline Cement & $280 \mathrm{~kg} / \mathrm{m}^{3}$ \\
Fly ash & $120 \mathrm{~kg} / \mathrm{m}^{3}$ \\
Slag & $50 \mathrm{~kg} / \mathrm{m}^{3}$ \\
Fine aggregate & $950 \mathrm{~kg} / \mathrm{m}^{3}$ \\
Coarse aggregate & $780 \mathrm{~kg} / \mathrm{m}^{3}$ \\
Water & $182 \mathrm{~kg} / \mathrm{m}^{3}$ \\
High Range Water Reducer (HRWR) & $3.3751 / \mathrm{m}^{3}$ \\
Water/Powder ratio & 0.4 \\
\hline
\end{tabular}

723 
Table 2: Details of tested specimens

\begin{tabular}{|c|c|c|c|c|c|c|c|c|}
\hline \multirow[t]{2}{*}{$\begin{array}{l}\text { Group } \\
\text { Name }\end{array}$} & \multirow[t]{2}{*}{$\begin{array}{l}\text { Specimen } \\
\text { Labels }\end{array}$} & \multicolumn{4}{|c|}{ Longitudinal Reinforcement } & \multicolumn{2}{|c|}{$\begin{array}{c}\text { Transverse } \\
\text { Reinforcement }\end{array}$} & \multirow[t]{2}{*}{$\begin{array}{c}\text { Loading } \\
\text { Modes }\end{array}$} \\
\hline & & $\begin{array}{c}\text { No. } \\
\text { of Bars } \\
\text { or Tubes }\end{array}$ & $\begin{array}{c}\text { Outside } \\
\text { Diameter } \\
\text { of Bars or } \\
\text { Tubes (mm) }\end{array}$ & $\begin{array}{c}\text { Thickness } \\
\text { of Tubes, } \\
\text { (mm) }\end{array}$ & $\begin{array}{c}\text { Reinforcement } \\
\text { Ratio, } \rho_{s} \\
(\%)\end{array}$ & $\begin{array}{l}\text { Pitch } \\
(\mathrm{mm})\end{array}$ & $\begin{array}{c}\text { Reinforcement } \\
\text { Ratio, } \rho_{s} \\
(\%)\end{array}$ & \\
\hline \multirow[t]{4}{*}{ N16-H50 } & N16-H50-C & 6 & $16(\mathrm{~N} 16)$ & - & 2.67 & 50 & 3.3 & \multirow{4}{*}{$\begin{array}{l}\text { Concentric } \\
\mathrm{e}=25 \mathrm{~mm} \\
\mathrm{e}=50 \mathrm{~mm} \\
\text { Flexural }\end{array}$} \\
\hline & N16-H50-E25 & 6 & $16(\mathrm{~N} 16)$ & - & 2.67 & 50 & 3.3 & \\
\hline & N16-H50-E50 & 6 & 16 (N16) & - & 2.67 & 50 & 3.3 & \\
\hline & N16-H50-F & 6 & $16(\mathrm{~N} 16)$ & - & 2.67 & 50 & 3.3 & \\
\hline \multirow[t]{4}{*}{ ST33.7-H50 } & ST33.7-H50-C & 6 & 33.7 & 2 & 2.64 & 50 & 3.3 & \multirow{4}{*}{$\begin{array}{l}\text { Concentric } \\
\mathrm{e}=25 \mathrm{~mm} \\
\mathrm{e}=50 \mathrm{~mm} \\
\text { Flexural }\end{array}$} \\
\hline & ST33.7-H50-E25 & 6 & 33.7 & 2 & 2.64 & 50 & 3.3 & \\
\hline & ST33.7-H50-E50 & 6 & 33.7 & 2 & 2.64 & 50 & 3.3 & \\
\hline & ST33.7-H50-F & 6 & 33.7 & 2 & 2.64 & 50 & 3.3 & \\
\hline \multirow[t]{4}{*}{ ST33.7-H75 } & ST33.7-H75-C & 6 & 33.7 & 2 & 2.64 & 75 & 2.2 & \multirow{4}{*}{$\begin{array}{l}\text { Concentric } \\
\mathrm{e}=25 \mathrm{~mm} \\
\mathrm{e}=50 \mathrm{~mm} \\
\text { Flexural }\end{array}$} \\
\hline & ST33.7-H75-E25 & 6 & 33.7 & 2 & 2.64 & 75 & 2.2 & \\
\hline & ST33.7-H75-E50 & 6 & 33.7 & 2 & 2.64 & 75 & 2.2 & \\
\hline & ST33.7-H75-F & 6 & 33.7 & 2 & 2.64 & 75 & 2.2 & \\
\hline \multirow[t]{4}{*}{ ST26.9-H50 } & ST26.9-H50-C & 6 & 26.9 & 2.6 & 2.63 & 50 & 3.3 & \multirow{4}{*}{$\begin{array}{l}\text { Concentric } \\
\mathrm{e}=25 \mathrm{~mm} \\
\mathrm{e}=50 \mathrm{~mm} \\
\text { Flexural }\end{array}$} \\
\hline & ST26.9-H50-E25 & 6 & 26.9 & 2.6 & 2.63 & 50 & 3.3 & \\
\hline & ST26.9-H50-E50 & 6 & 26.9 & 2.6 & 2.63 & 50 & 3.3 & \\
\hline & ST26.9-H50-F & 6 & 26.9 & 2.6 & 2.63 & 50 & 3.3 & \\
\hline \multirow[t]{4}{*}{ ST26.9-H75 } & ST26.9-H75-C & 6 & 26.9 & 2.6 & 2.63 & 75 & 2.2 & \multirow{4}{*}{$\begin{array}{l}\text { Concentric } \\
\mathrm{e}=25 \mathrm{~mm} \\
\mathrm{e}=50 \mathrm{~mm} \\
\text { Flexural }\end{array}$} \\
\hline & ST26.9-H75-E25 & 6 & 26.9 & 2.6 & 2.63 & 75 & 2.2 & \\
\hline & ST26.9-H75-E50 & 6 & 26.9 & 2.6 & 2.63 & 75 & 2.2 & \\
\hline & ST26.9-H75-F & 6 & 26.9 & 2.6 & 2.63 & 75 & 2.2 & \\
\hline
\end{tabular}


Table 3: Results of specimens tested under concentric loading

\begin{tabular}{lccccc}
\hline Specimen & N16H50C & ST33.7H50C & ST26.9H50C & ST33.7H75C & ST26.9H75C \\
\hline Yield load (kN) & 2505 & 2500 & 2375 & 2395 & 2275 \\
$\begin{array}{l}\text { Corresponding axial } \\
\text { deformation (mm) }\end{array}$ & 2.35 & 2.45 & 2.35 & 2.65 & 2.2 \\
Maximum load (kN) & 2734 & 2729 & 2598 & 2633 & 2443 \\
$\begin{array}{l}\text { Corresponding axial } \\
\text { deformation (mm) }\end{array}$ & 3.08 & 3.29 & 3.03 & 3.44 & 2.79 \\
$\begin{array}{l}\text { Ultimate axial } \\
\text { deformation (mm)* }\end{array}$ & 20 & 33.5 & 36 & 26.2 & 30.4 \\
Ductility & 16.96 & 22 & 22.84 & 13.91 & 18.91 \\
\hline * Ultimate axial deformation
\end{tabular}

* Ultimate axial deformation was defined by the fracture of the steel helices. 
Table 4: Results of specimens tested under $25 \mathrm{~mm}$ eccentric loading

\begin{tabular}{|c|c|c|c|c|c|}
\hline Specimen & N16H50E25 & ST33.7H50E25 & ST26.9H50E25 & ST33.7H75E25 & ST26.9H75E25 \\
\hline Yield load $(\mathrm{kN})$ & 1690 & 1685 & 1650 & 1675 & 1545 \\
\hline $\begin{array}{l}\text { Corresponding axial } \\
\text { deformation }(\mathrm{mm})\end{array}$ & 2.6 & 2.4 & 2.5 & 2.5 & 2.35 \\
\hline Maximum load (kN) & 1824 & 1820 & 1780 & 1782 & 1631 \\
\hline $\begin{array}{l}\text { Corresponding axial } \\
\text { deformation }(\mathrm{mm})\end{array}$ & 3.11 & 2.93 & 3.24 & 3.18 & 2.86 \\
\hline $\begin{array}{l}\text { Corresponding lateral } \\
\text { deformation }(\mathrm{mm})\end{array}$ & 2.49 & 2.42 & 2.95 & 2.04 & 2.47 \\
\hline $\begin{array}{l}\text { Ultimate axial } \\
\text { deformation }(\mathrm{mm})^{*}\end{array}$ & 26.3 & 20.2 & 20.7 & 20 & 20.2 \\
\hline Ductility & 13.1 & 8.56 & 8.3 & 7.23 & 7.37 \\
\hline
\end{tabular}

* Ultimate axial deformation was defined by $75 \%$ of the maximum load. 
Table 5: Results of specimens tested under $50 \mathrm{~mm}$ eccentric loading

\begin{tabular}{|c|c|c|c|c|c|}
\hline Specimen & N16H50E50 & ST33.7H50E50 & ST26.9H50E50 & ST33.7H75E50 & ST26.9H75E50 \\
\hline Yield load $(\mathrm{kN})$ & 1200 & 1145 & 1185 & 1150 & 1100 \\
\hline $\begin{array}{l}\text { Corresponding axial } \\
\text { deformation }(\mathrm{mm})\end{array}$ & 2.5 & 2.4 & 2.5 & 2.4 & 2.35 \\
\hline Maximum load $(\mathrm{kN})$ & 1300 & 1233 & 1267 & 1240 & 1175 \\
\hline $\begin{array}{l}\text { Corresponding axial } \\
\text { deformation (mm) }\end{array}$ & 2.78 & 2.84 & 2.9 & 2.92 & 2.73 \\
\hline $\begin{array}{l}\text { Corresponding lateral } \\
\text { deformation }(\mathrm{mm})\end{array}$ & 2.94 & 2.87 & 3 & 3.5 & 3.24 \\
\hline $\begin{array}{l}\text { Ultimate axial } \\
\text { deformation }(\mathrm{mm})^{*}\end{array}$ & 20.7 & 14.7 & 20.7 & 18.4 & 25.1 \\
\hline Ductility & 11.54 & 8.7 & 8.63 & 7.56 & 9.78 \\
\hline
\end{tabular}

* Ultimate axial deformation was defined by $75 \%$ of the maximum load. 
Table 6: Results of specimens tested under flexural loading

\begin{tabular}{|c|c|c|c|c|c|}
\hline Specimen & $\mathrm{N} 16 \mathrm{H} 50 \mathrm{~F}$ & ST33.7H50F & ST26.9H50F & ST33.7H75F & ST26.9H75F \\
\hline Yield load (kN) & 510 & 490 & 385 & 458 & 350 \\
\hline $\begin{array}{l}\text { Corresponding midspan } \\
\text { deflection }(\mathrm{mm})\end{array}$ & 4.5 & 4.95 & 5.1 & 4.75 & 4.35 \\
\hline Maximum load $(\mathrm{kN})$ & 592 & 541 & 443 & 511 & 401 \\
\hline $\begin{array}{l}\text { Corresponding midspan } \\
\text { deflection }(\mathrm{mm})\end{array}$ & 26.8 & 7.2 & 9.07 & 6.59 & 6.02 \\
\hline $\begin{array}{l}\text { Ultimate midspan } \\
\text { deflection }(\mathrm{mm})^{*}\end{array}$ & 44.1 & 47.5 & 39.8 & 37.9 & 23.9 \\
\hline Ductility & 17.55 & 12.49 & 9.63 & 11.7 & 8.52 \\
\hline
\end{tabular}



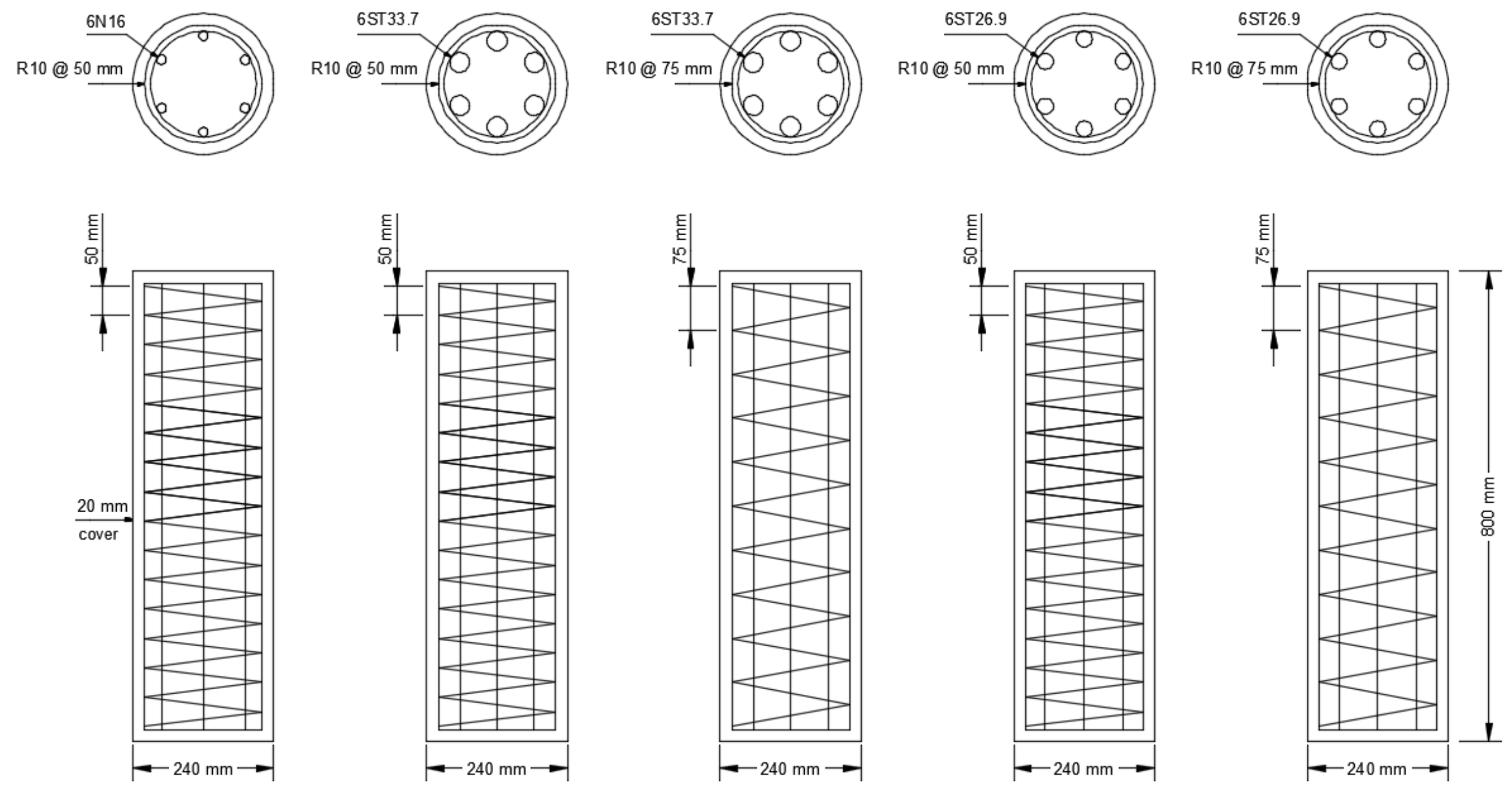

Group N16-H50 


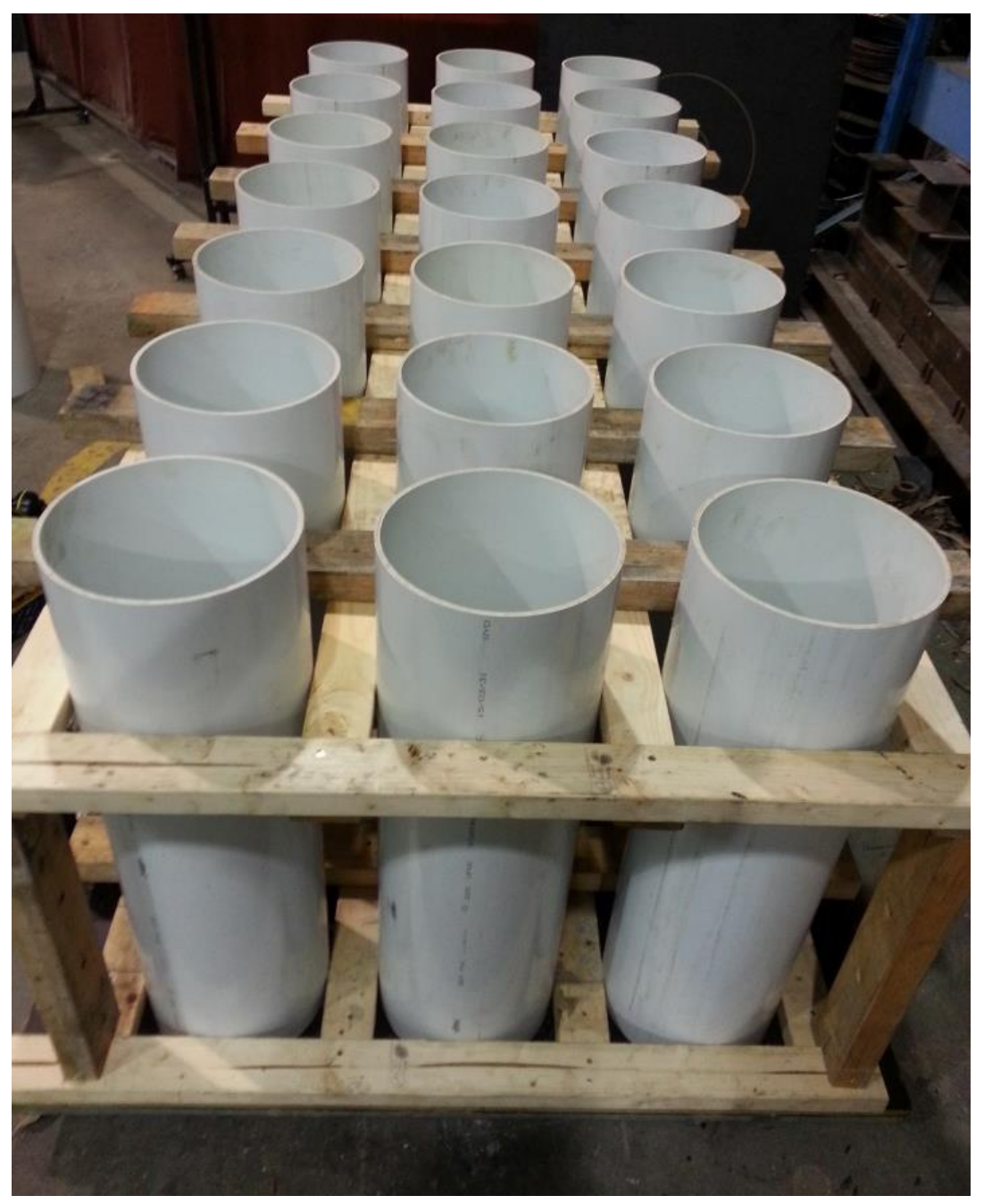




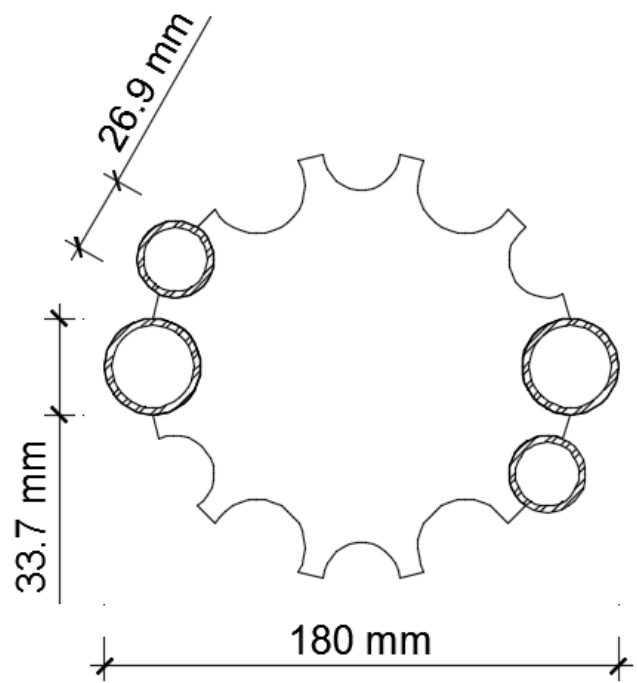

Circular template 1

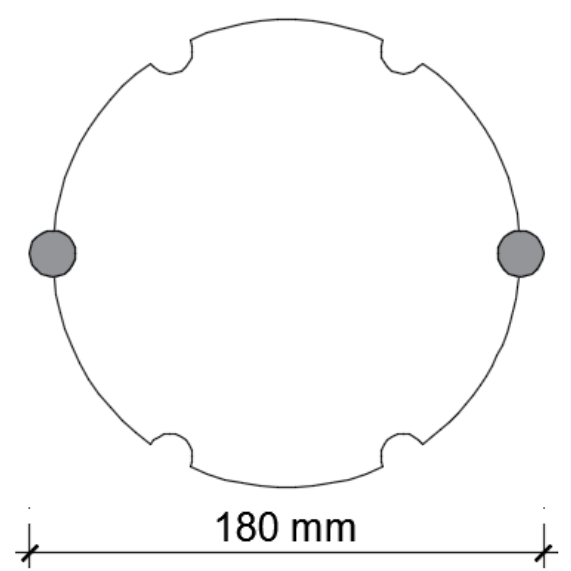

Circular template 2 


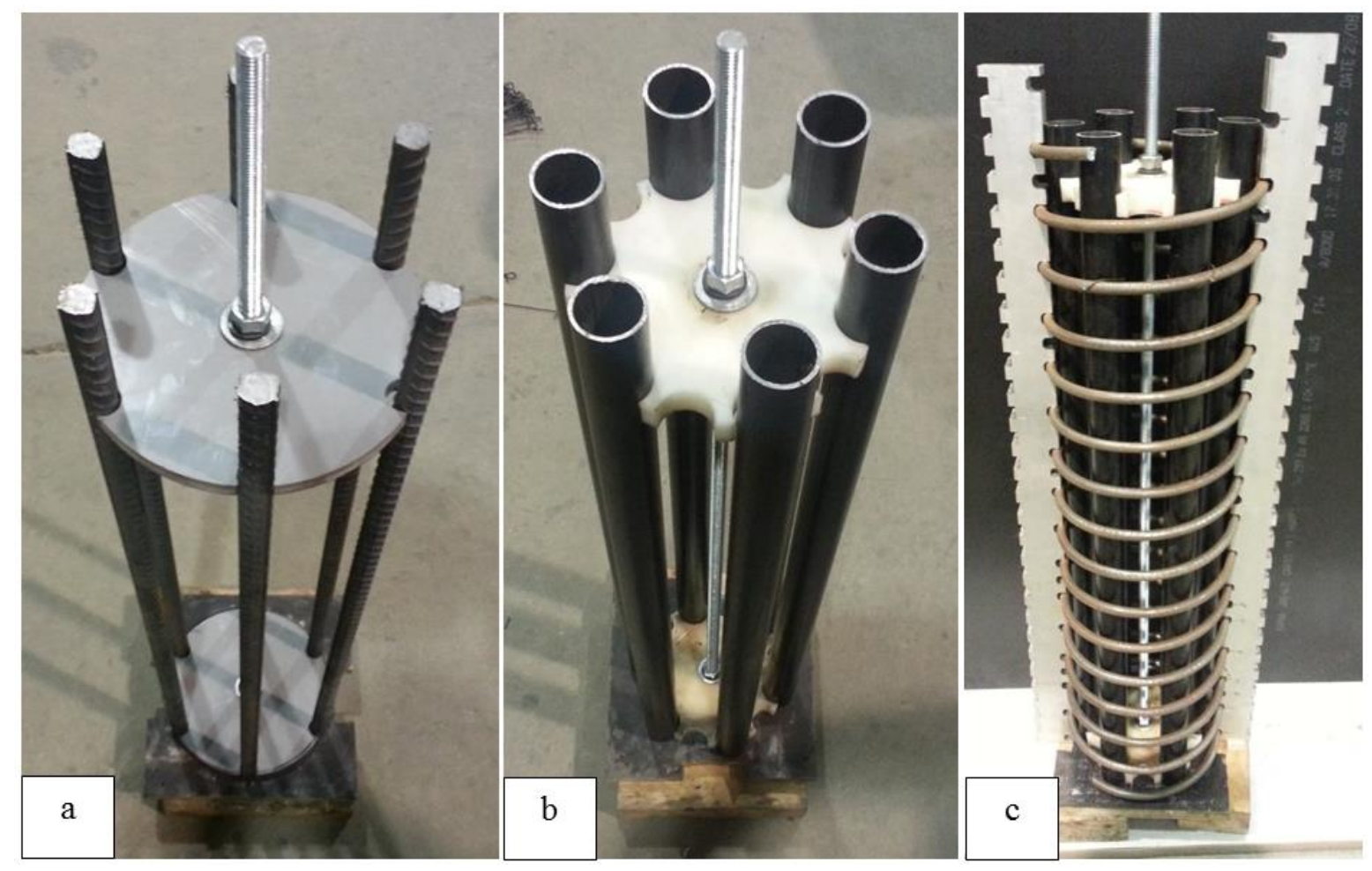




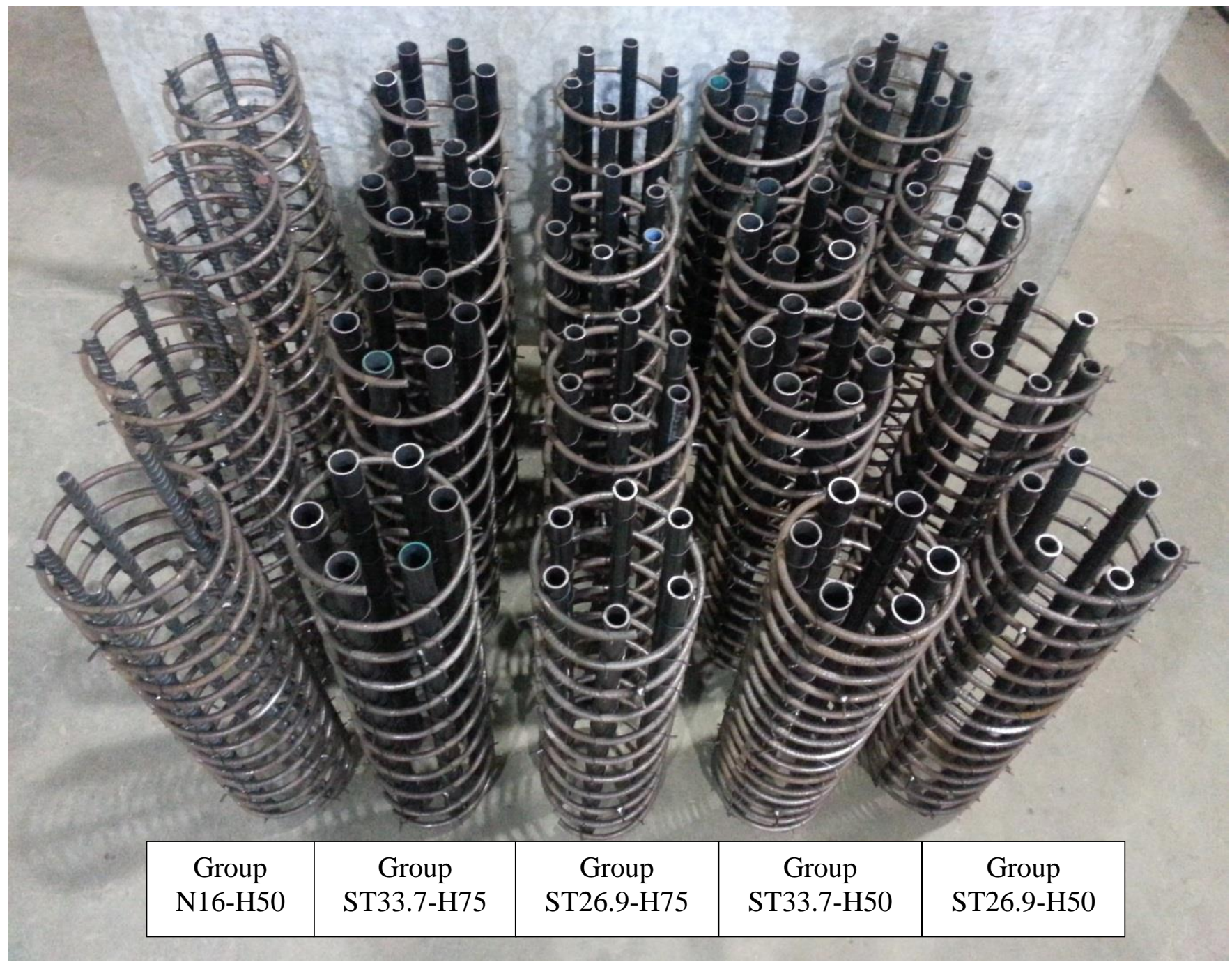




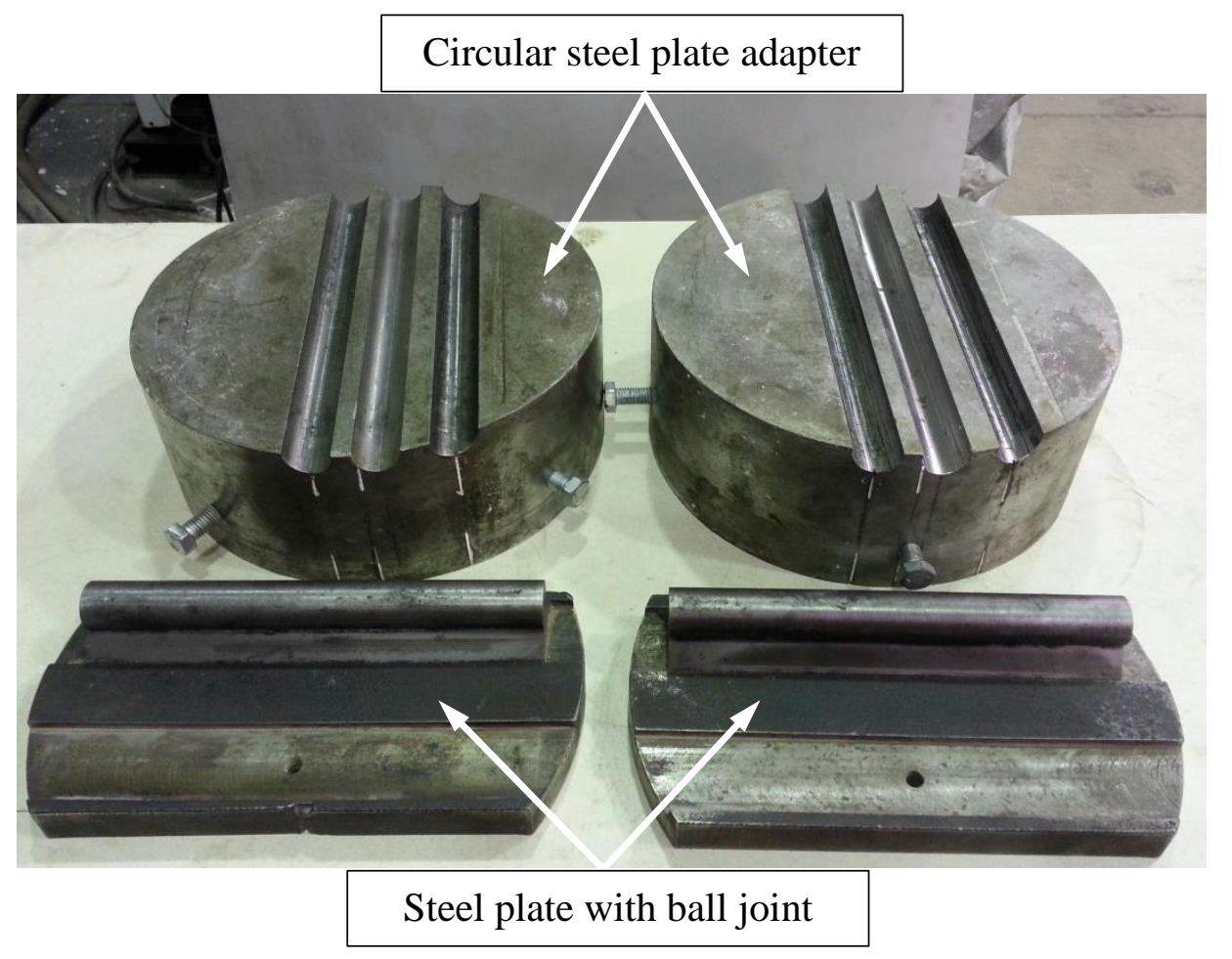

(a) Loading heads

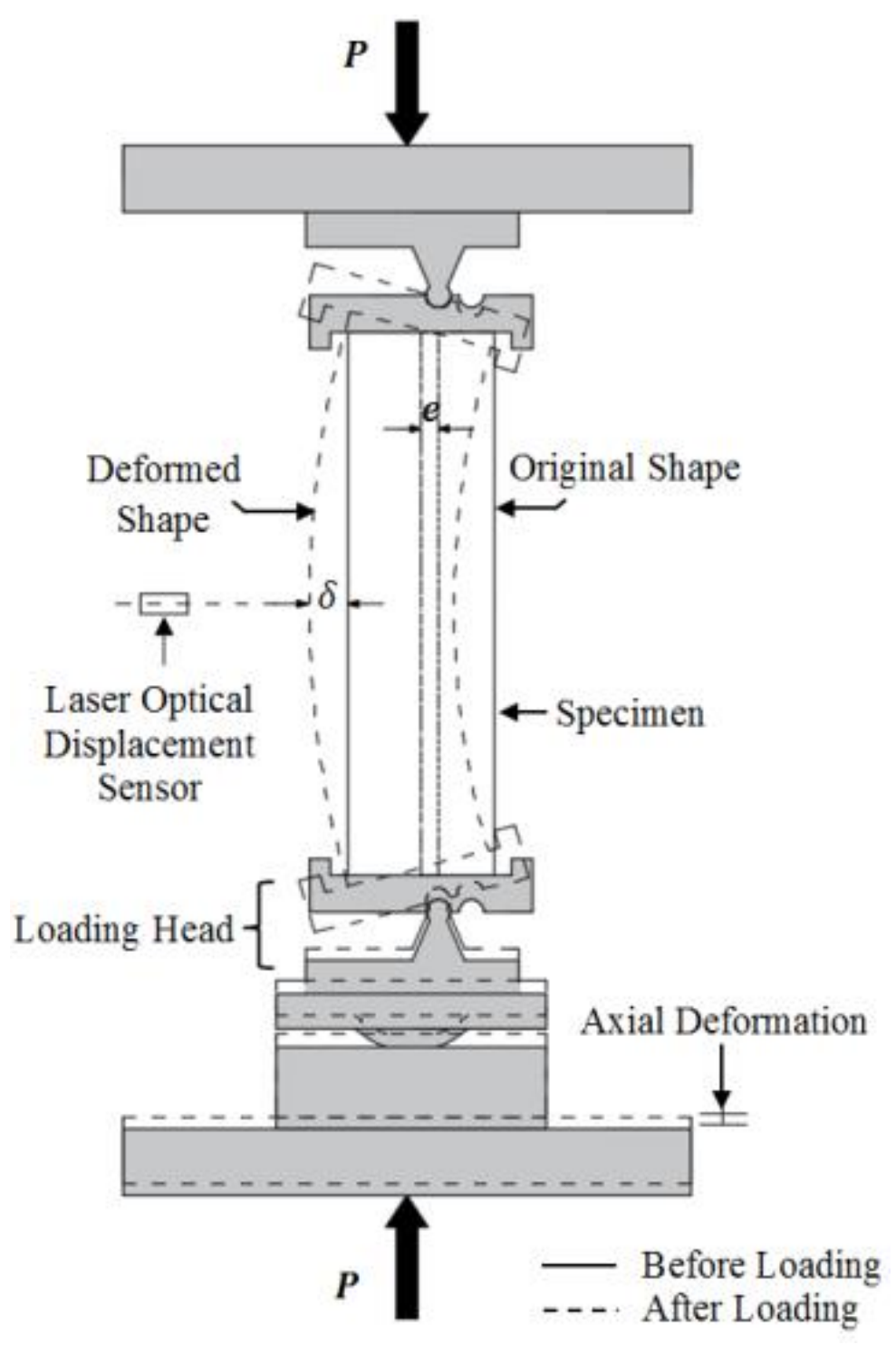

(b) Setup details of specimen 


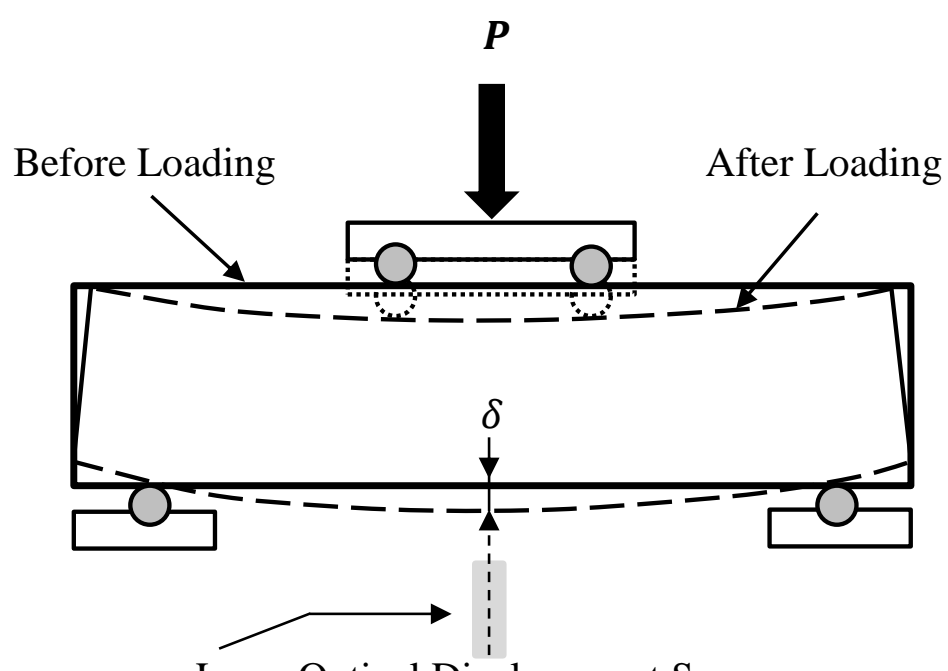

Laser Optical Displacement Sensor

$$
\text { ץ } \frac{l}{3} \div \frac{l}{3}+\frac{l}{3} \rightarrow
$$




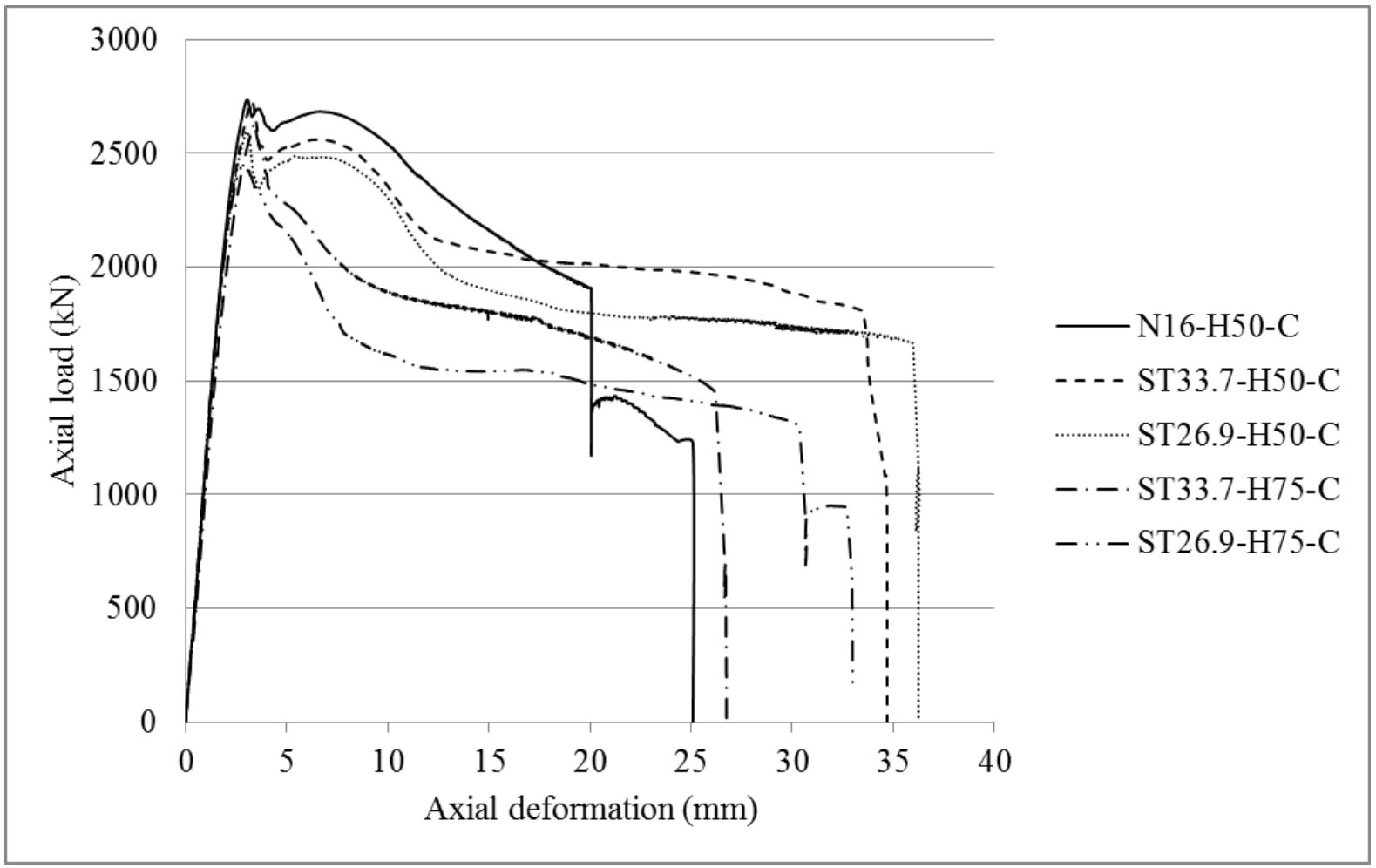




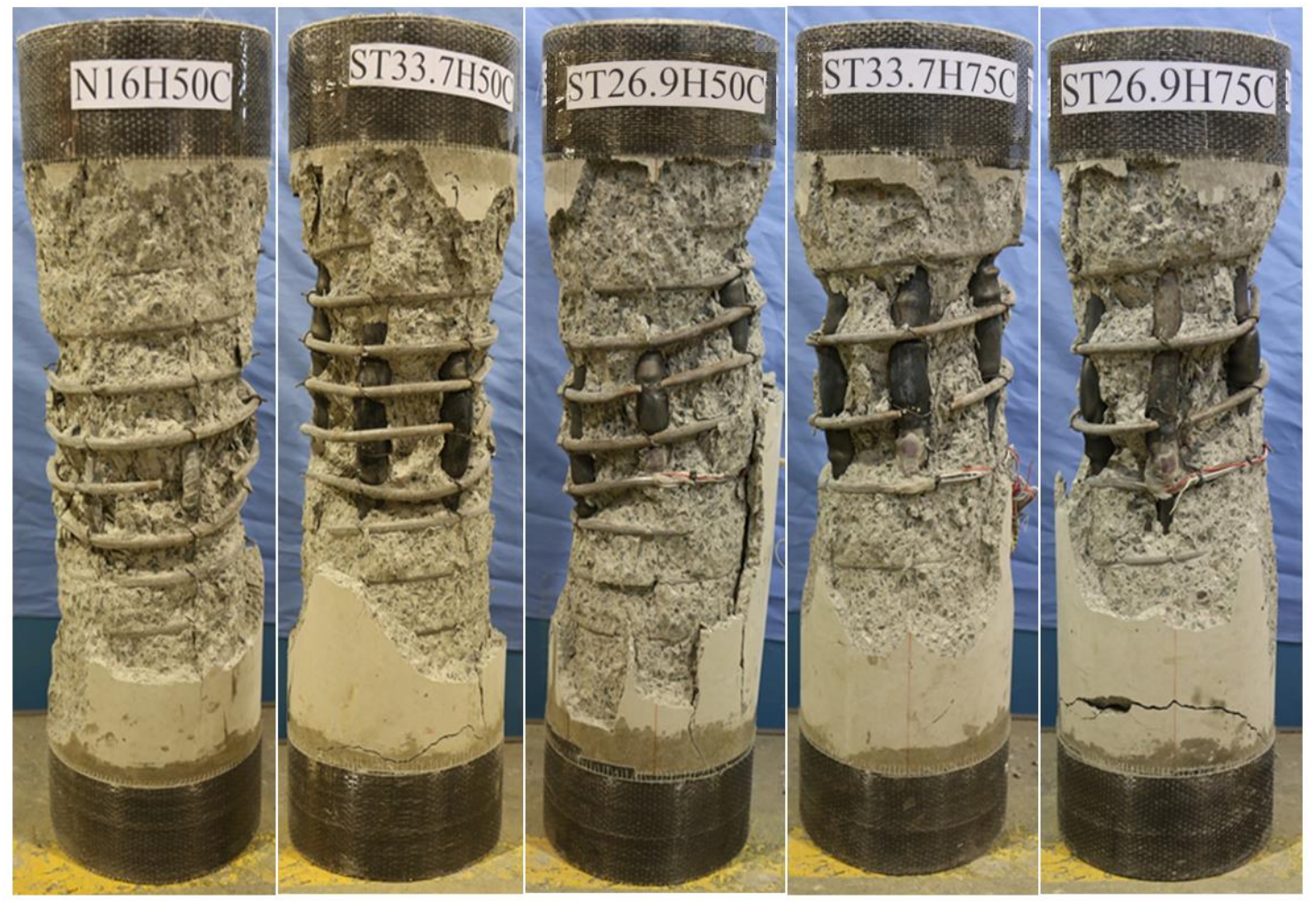




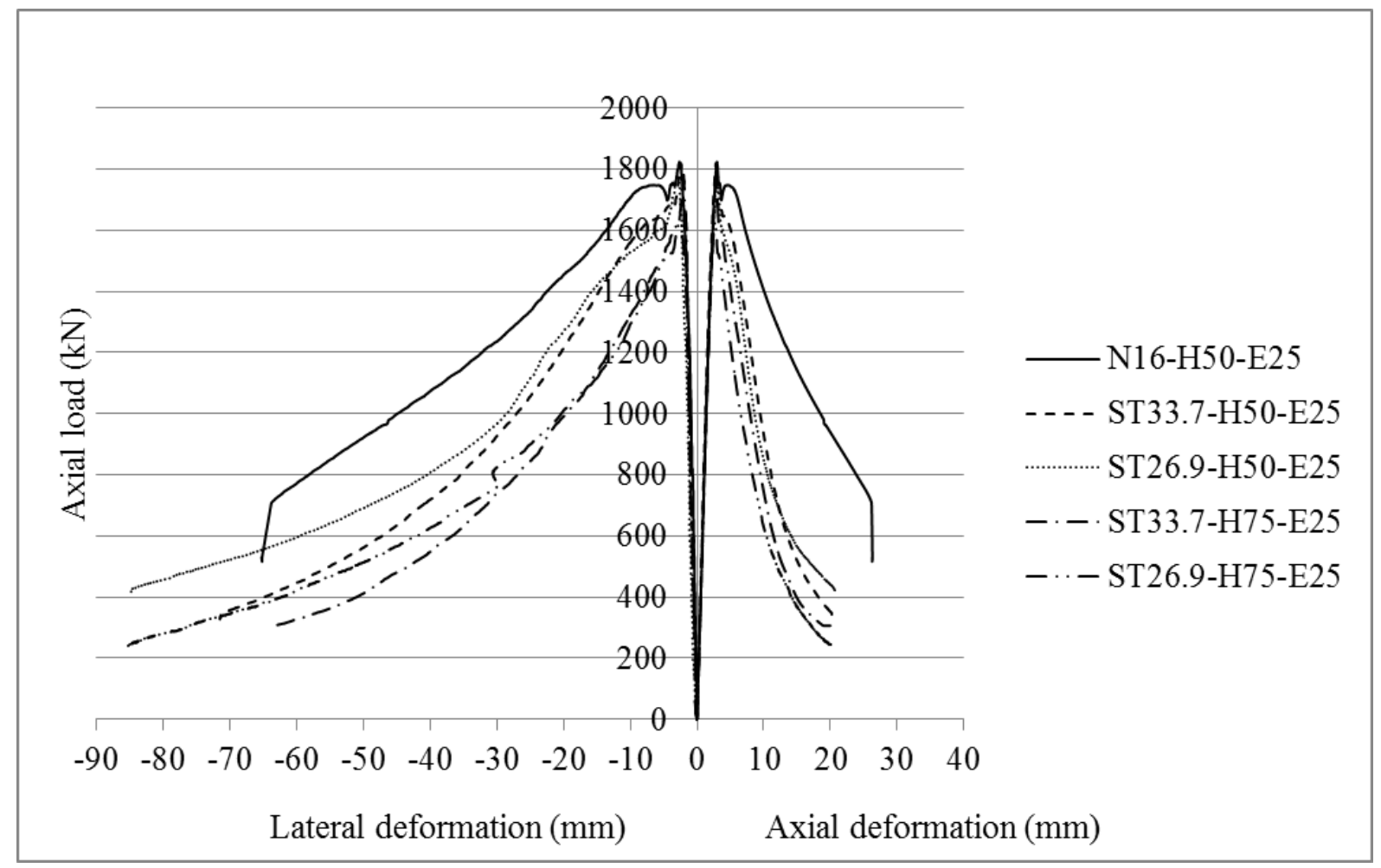




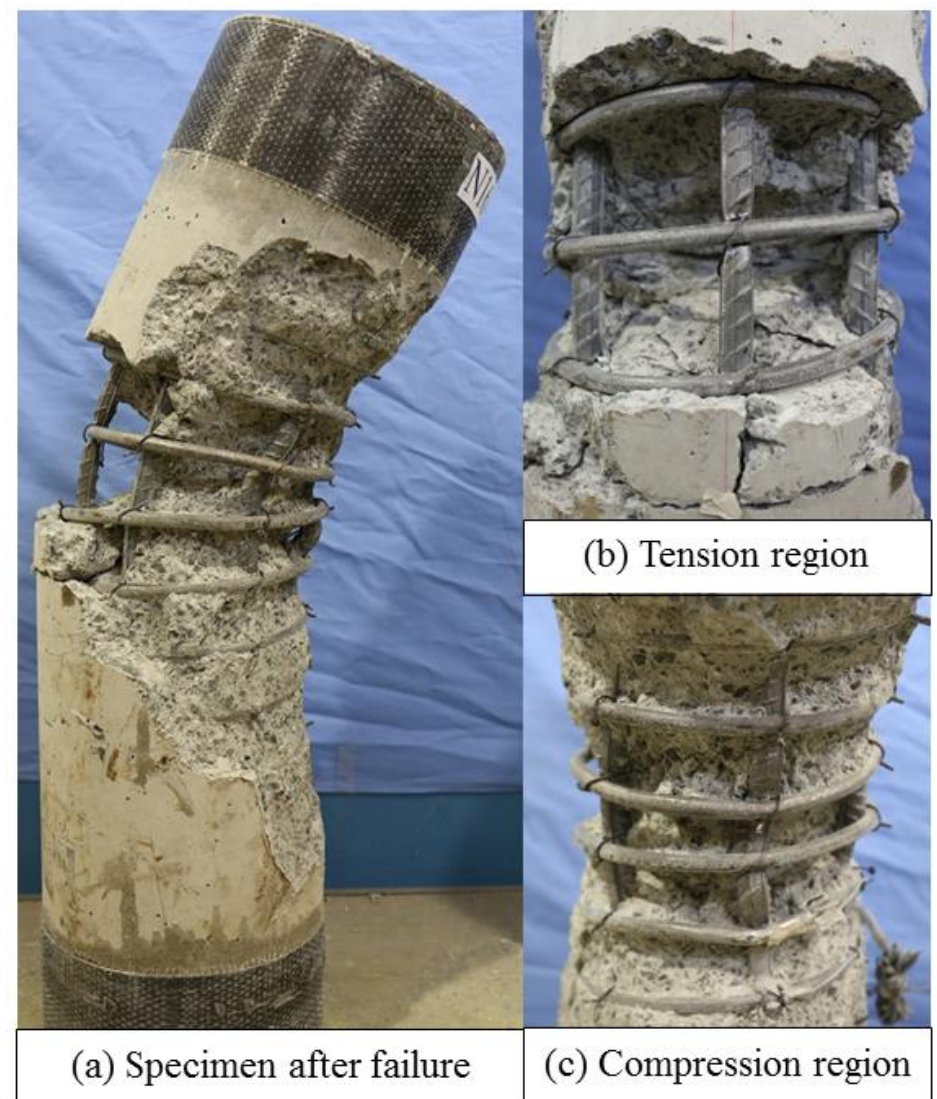



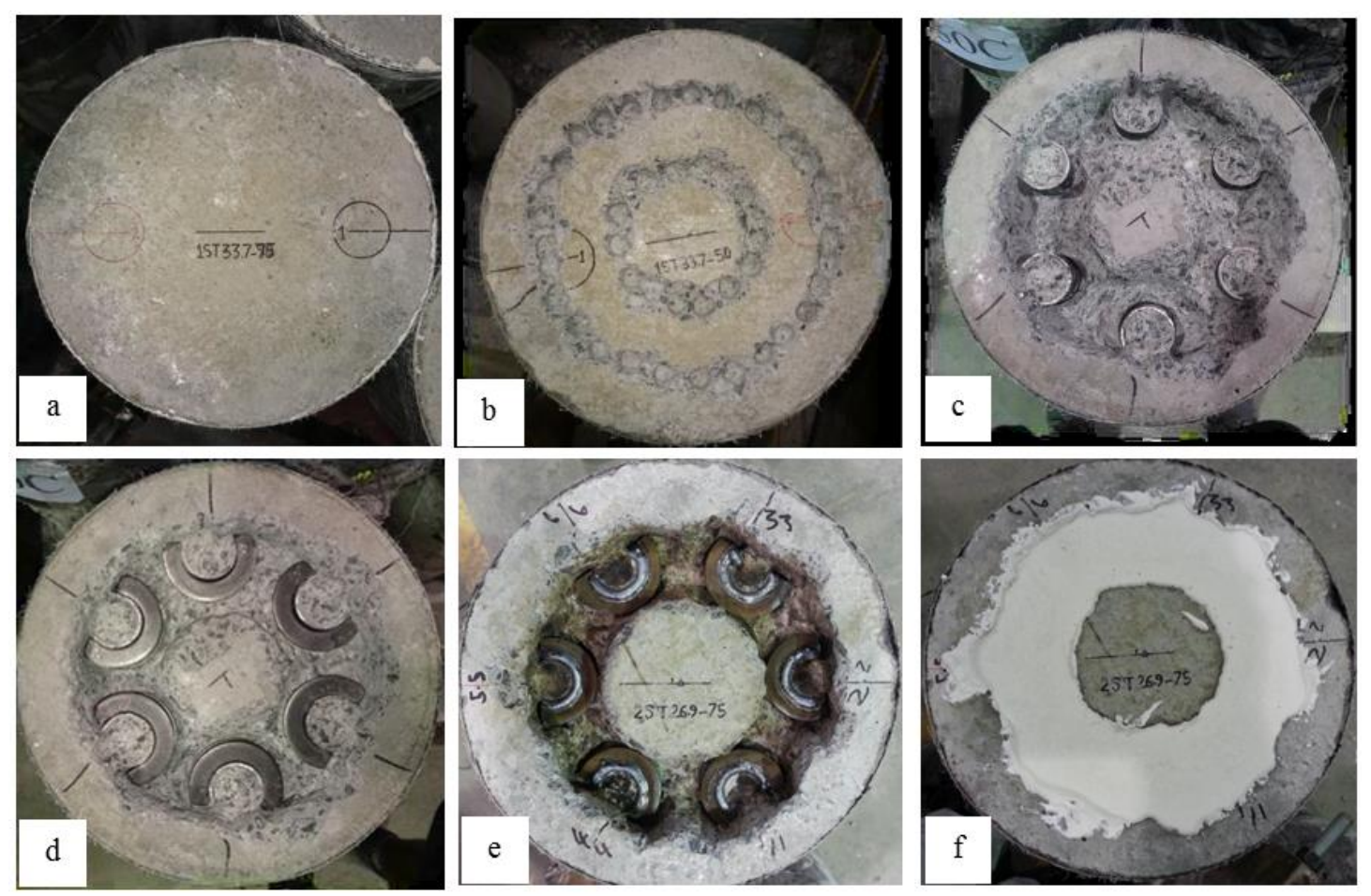


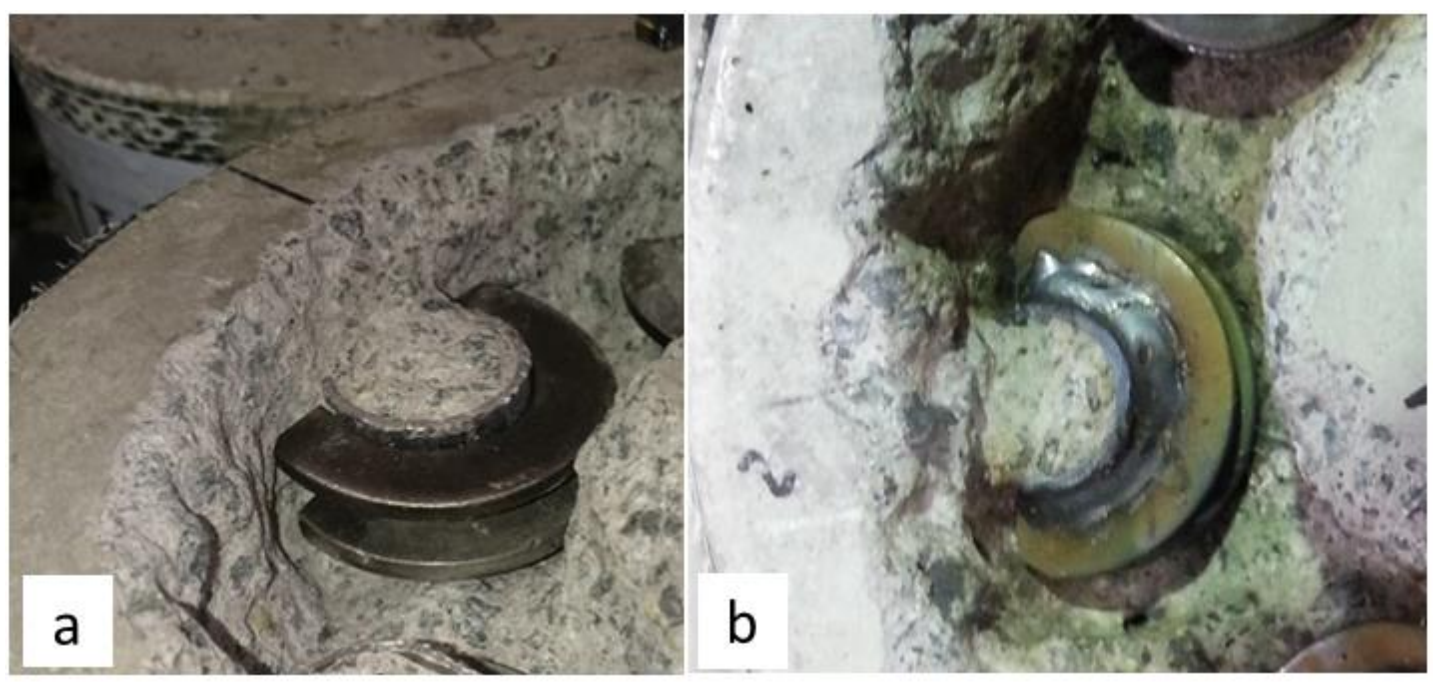




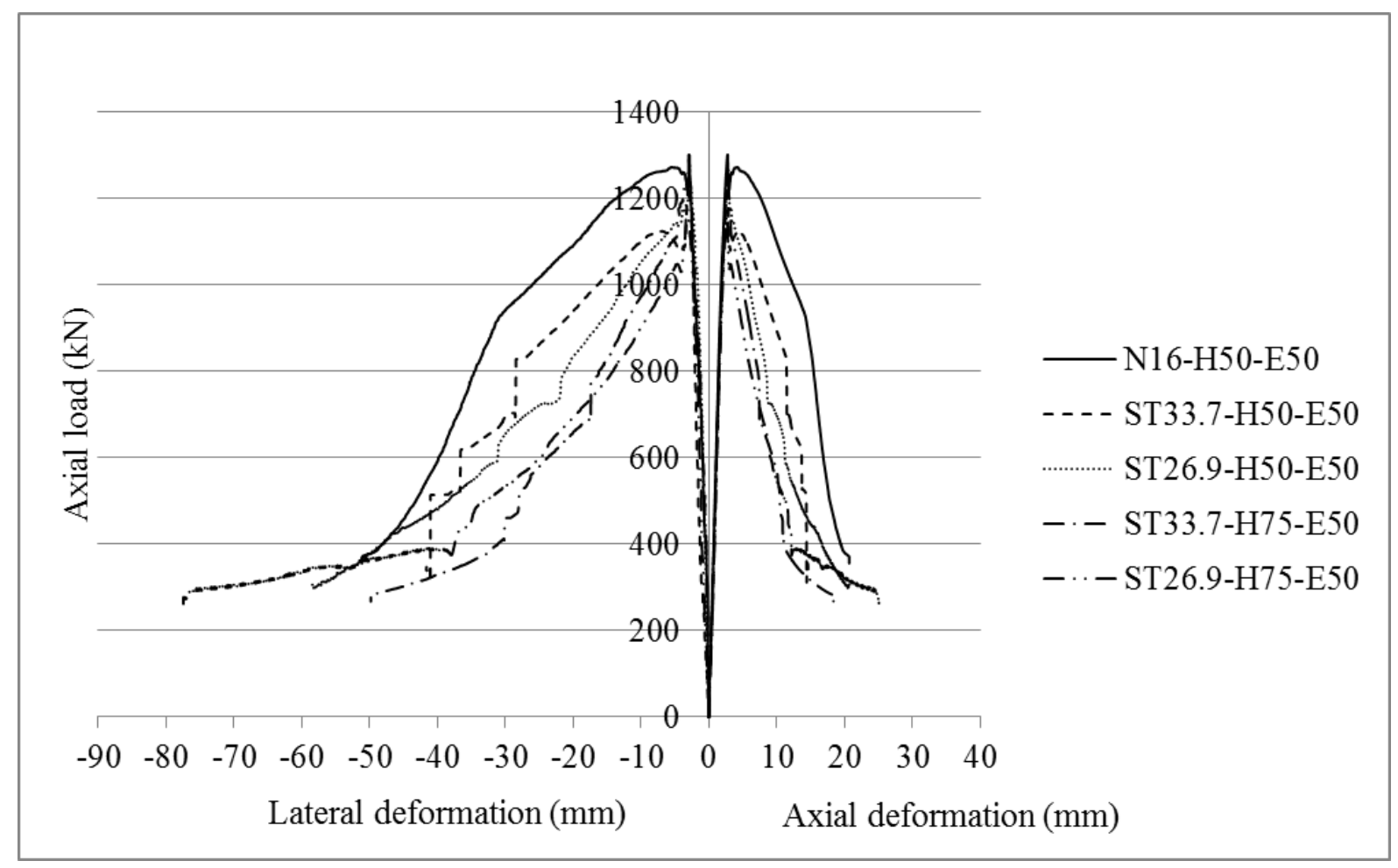




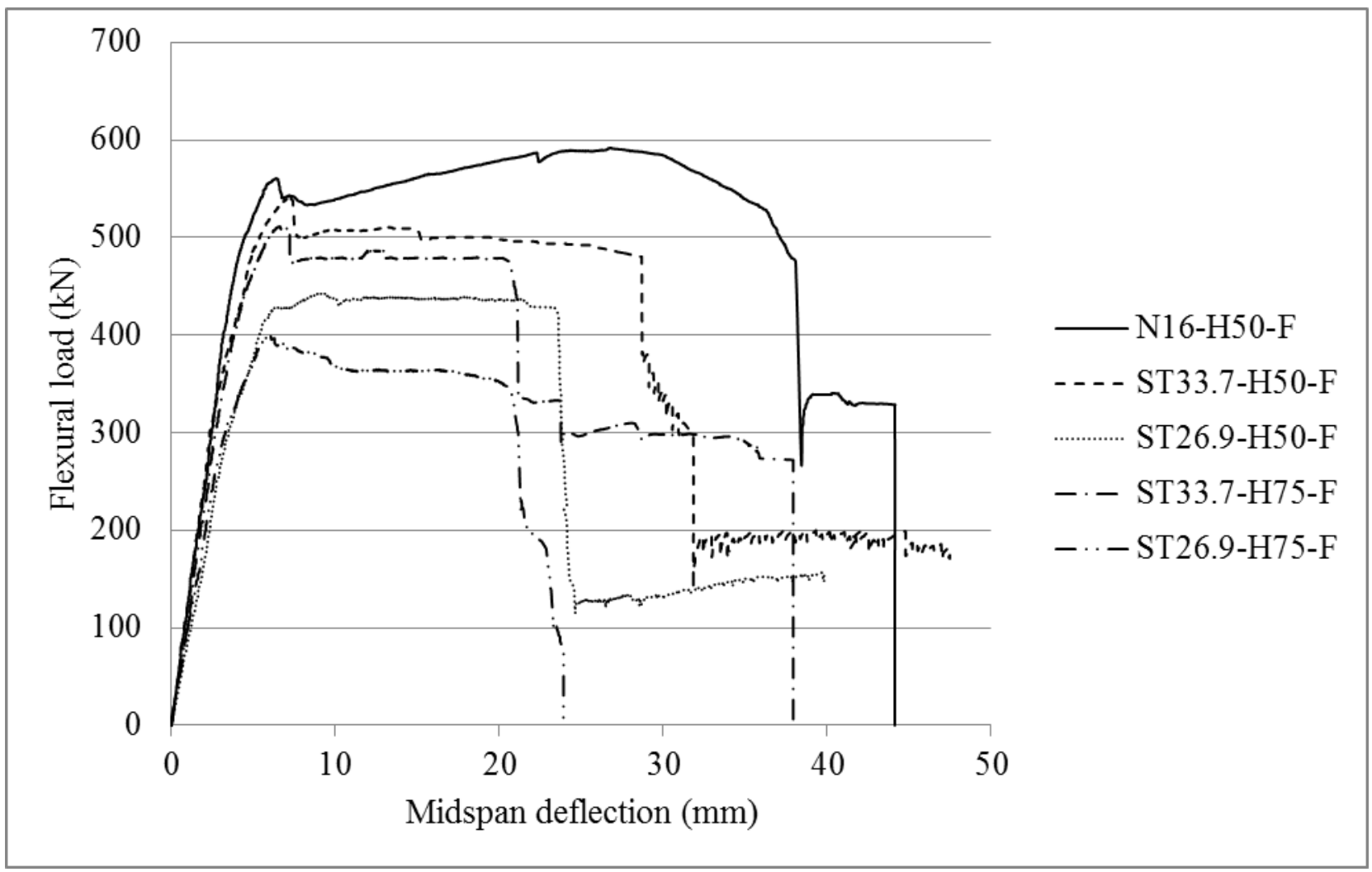




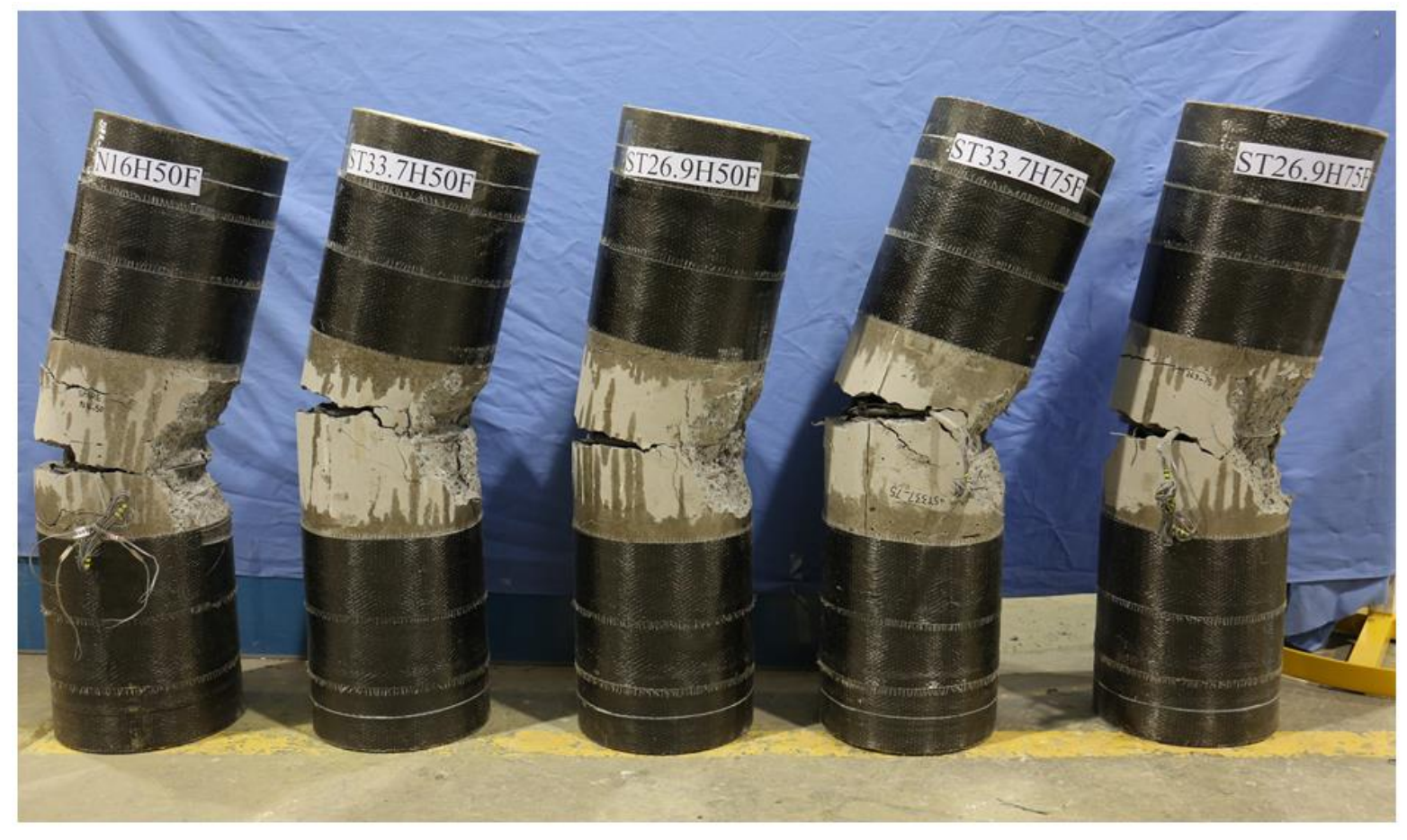




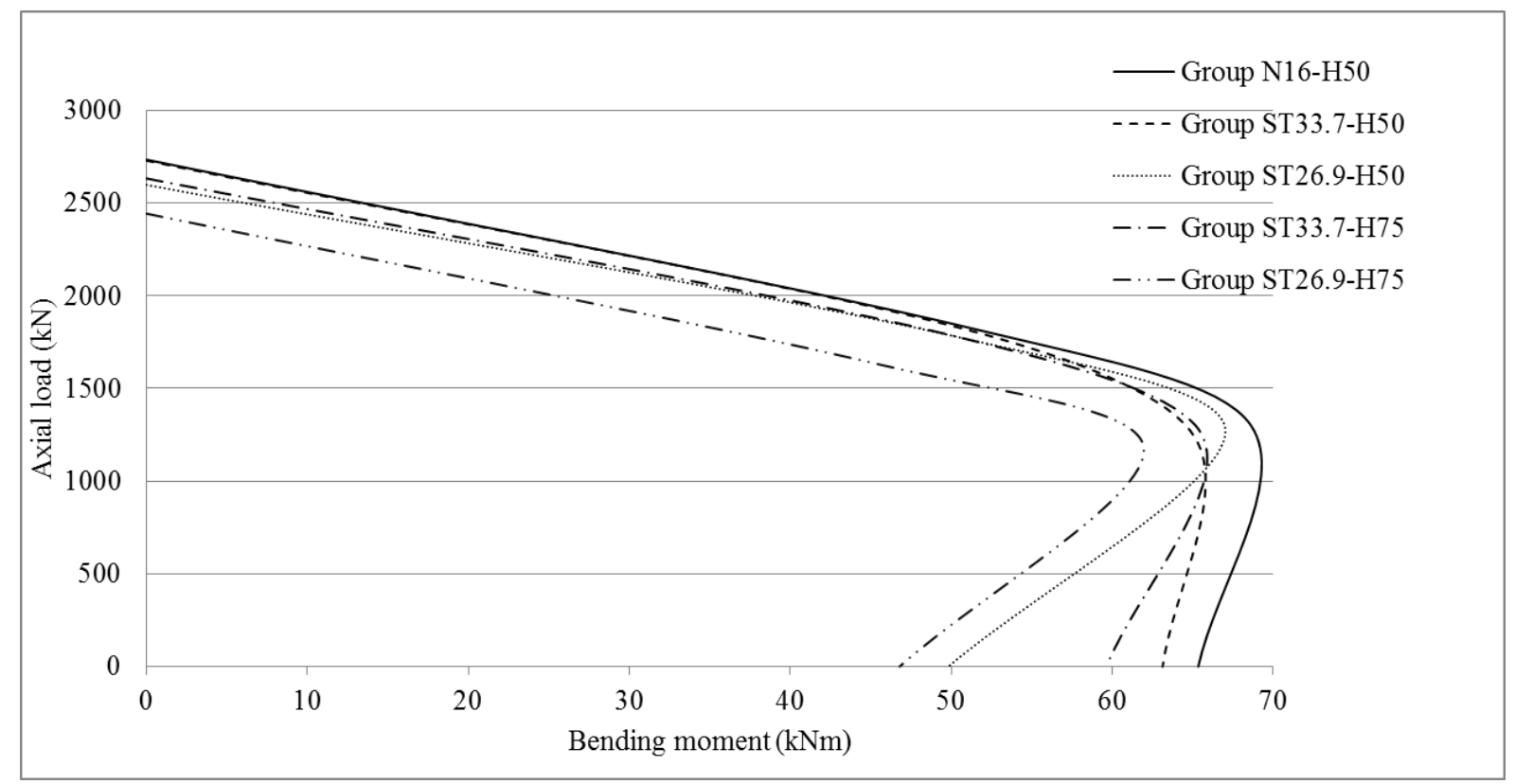




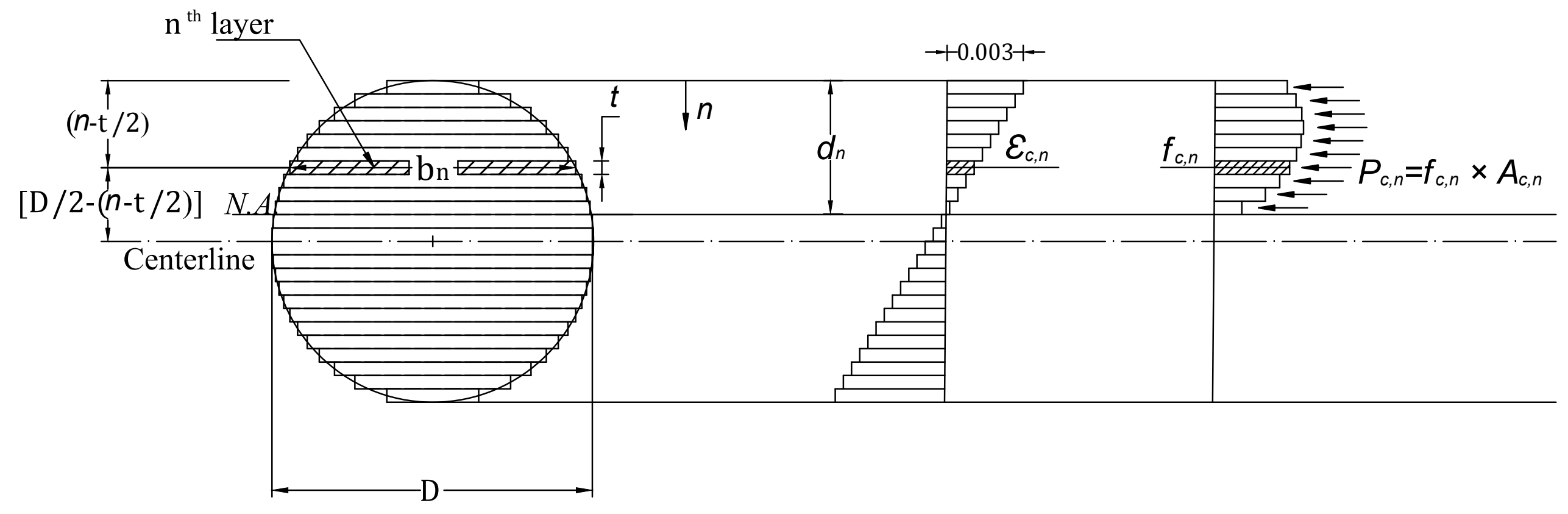

Cross-section divided into $n$ number of layers
Strain distribution

Corresponding stress and force distribution 

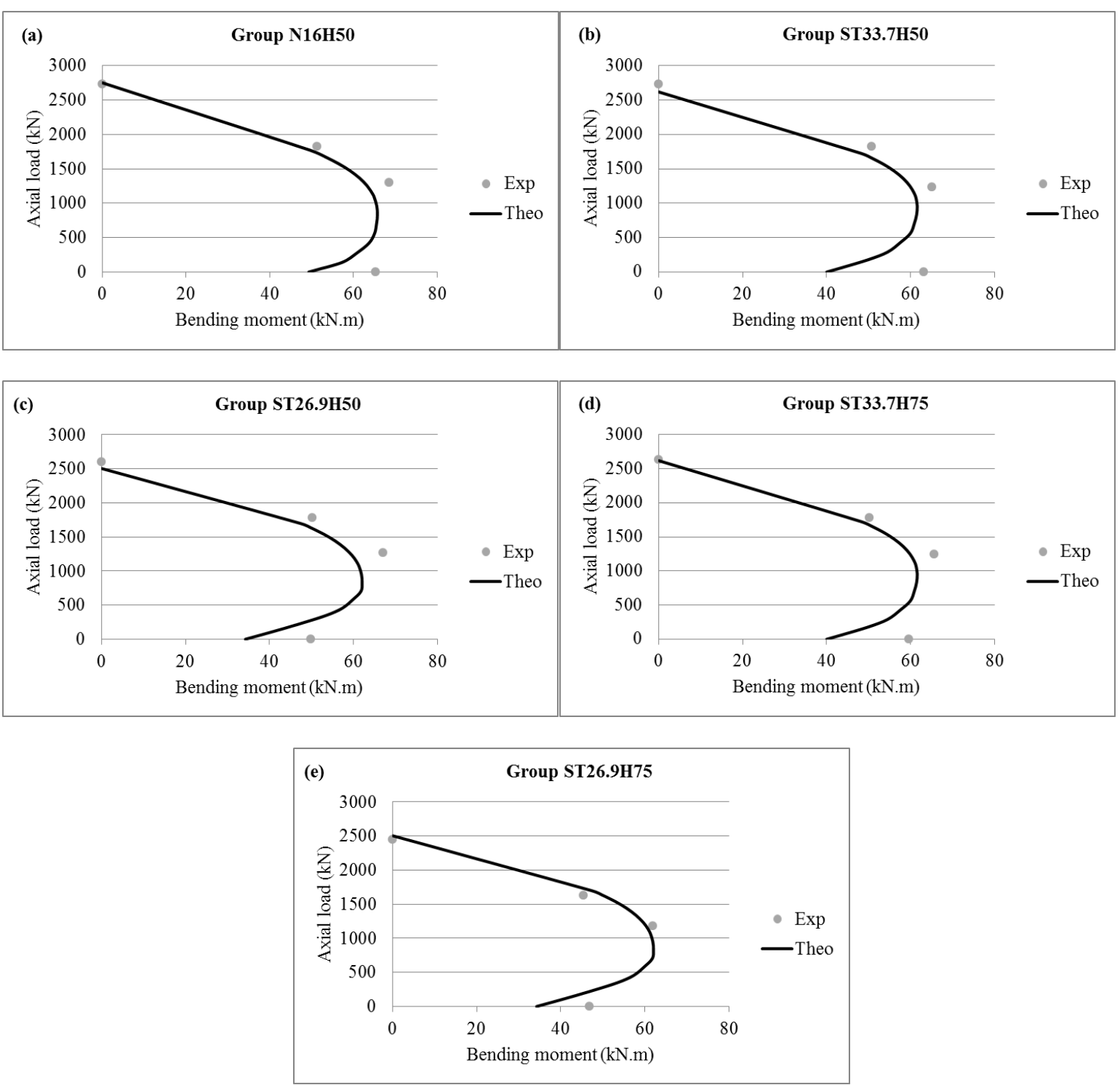